\title{
Shipborne measurements of methane and carbon dioxide in the Middle East and Mediterranean areas and the contribution from oil and gas emissions
}

\author{
Jean-Daniel Paris ${ }^{1,2}$, Aurélie Riandet ${ }^{1, a}$, Efstratios Bourtsoukidis ${ }^{3,2}$, Marc Delmotte $^{1}$, Antoine Berchet ${ }^{1}$, \\ Jonathan Williams ${ }^{3,2}$, Lisa Ernle ${ }^{3}$, Ivan Tadic ${ }^{3}$, Hartwig Harder ${ }^{3}$, and Jos Lelieveld ${ }^{3,2}$ \\ ${ }^{1}$ Laboratoire des Sciences du Climat et de l'Environnement, CEA-CNRS-UVSQ, UMR8212, IPSL, Gif-sur-Yvette, France \\ ${ }^{2}$ Climate and Atmosphere Research Centre (CARE-C), The Cyprus Institute, Nicosia, 2121, Cyprus \\ ${ }^{3}$ Department of Atmospheric Chemistry, Max Planck Institute for Chemistry, Mainz 55128, Germany \\ anow at: Aix Marseille Université, CNRS, Avignon Université, IRD, IMBE, Aix-en-Provence, France
}

Correspondence: Jean-Daniel Paris (jean-daniel.paris@lsce.ipsl.fr)

Received: 9 February 2021 - Discussion started: 5 March 2021

Revised: 17 July 2021 - Accepted: 19 July 2021 - Published: 19 August 2021

\begin{abstract}
The increase of atmospheric methane $\left(\mathrm{CH}_{4}\right)$ and carbon dioxide $\left(\mathrm{CO}_{2}\right)$, two of the main anthropogenic greenhouse gases, is largely driven by fossil sources. Sources and sinks remain insufficiently characterized in the Mediterranean and Middle East areas, where very few in situ measurements are available. We measured the atmospheric mixing ratios of $\mathrm{CH}_{4}$ and $\mathrm{CO}_{2}$ by ship in the region in July and August 2017. High mixing ratios were observed over the Suez Canal, Red Sea and Arabian Gulf, while generally lower mixing ratios were observed over the Gulf of Aden and Gulf of Oman. We probe the origin of the $\mathrm{CO}_{2}$ and $\mathrm{CH}_{4}$ excess mixing ratio by using correlations with light alkanes and through the use of a Lagrangian model coupled to two different emission inventories of anthropogenic sources. We find that the $\mathrm{CO}_{2}$ and especially the $\mathrm{CH}_{4}$ enhancements are mainly linked to nearby oil and gas (OG) activities over the Arabian Gulf and a mixture of other sources over the Red Sea. The isomeric ratio of pentane is shown to be a useful indicator of the OG component of atmospheric $\mathrm{CH}_{4}$ at the regional level. Upstream emissions linked to oil in the northern Arabian Gulf seem to be underestimated, while gas-related emissions in the southern Gulf are overestimated in our simulations. Our results highlight the need for improvement of inventories in the area to better characterize the changes in magnitude and the complex distribution of the OG sources in the Middle East.
\end{abstract}

\section{Introduction}

Methane $\left(\mathrm{CH}_{4}\right)$ and carbon dioxide $\left(\mathrm{CO}_{2}\right)$ are potent anthropogenic greenhouse gases (GHGs). The $\mathrm{CH}_{4}$ atmospheric mole fraction has increased by $150 \%$ since the preindustrial era (Saunois et al., 2020). Over a 100-year horizon, $\mathrm{CH}_{4}$ has a global warming potential 28 times larger than $\mathrm{CO}_{2}$. Roughly half of $\mathrm{CH}_{4}$ sources are of natural origin (mainly from wetlands, with contributions from fires and geologic sources). The remainder is anthropogenic, mainly linked to fossil fuels, agriculture (including enteric fermentation in ruminants, manure management and rice paddies) and waste management. The increasing anthropogenic emissions are driven equally by fossil fuel sources and agricultural sources (Jackson et al., 2020).

$\mathrm{CO}_{2}$ concentration in the atmosphere has increased by $47 \%$ since the preindustrial era and reached $407.38 \pm 0.10 \mathrm{ppm}$ in 2018 (Dlugokencky and Tans, 2018; Le Quéré et al., 2018; Friedlingstein et al., 2019). Its increase is caused primarily by the use of fossil fuel, cement production and land use change and is partly mitigated by uptake in terrestrial ecosystems and the ocean. Over the last decade (2009-2018) $\mathrm{CO}_{2}$ sources have been dominated by fossil

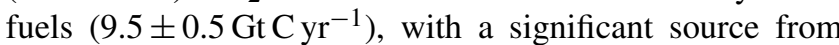
land use change $\left(1.5 \pm 0.7 \mathrm{Gt} \mathrm{C} \mathrm{yr}^{-1}\right)$. $\mathrm{CO}_{2}$ is removed from

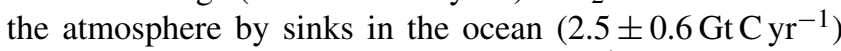
and land ecosystems $\left(3.2 \pm 0.6 \mathrm{GtC} \mathrm{yr}^{-1}\right.$; Friedlingstein et al., 2020). Atmospheric $\mathrm{CO}_{2}$ is expected to continue its 
growth despite widespread adoption of climate policies as oil and gas consumption trends suggest a continued increase in fossil $\mathrm{CO}_{2}$ emission (Jackson et al., 2019).

The 2015 Paris Agreement has set the objective to limit global temperatures below $1.5^{\circ} \mathrm{C}$. To reach this objective, a corridor of compliant emission pathways has been designed that require strong reductions not only in $\mathrm{CO}_{2}$ emissions but also in anthropogenic $\mathrm{CH}_{4}$ emissions (Jones et al., 2018; Nisbet et al., 2020). Regarding $\mathrm{CH}_{4}$, a wide array of measures is necessary (Nisbet et al., 2020), with a potentially high mitigation impact in the energy, agricultural and waste management sectors (Rogelj et al., 2018). Rapid and efficient mitigation options are readily available for methane emissions. A total of $80 \%$ of economically feasible abatements reside in the oil and gas (OG) sector (Ocko et al., 2021). IEA (2020) reviewed a number of efficient and cost-effective abatement options for the OG sector and found that $40 \%$ of OG methane emissions could be avoided at a zero net cost.

Fossil fuel production and use is responsible for the release of $112 \mathrm{MtCH}_{4} \mathrm{yr}^{-1}$ to the atmosphere, representing $33 \%$ of the total anthropogenic emission of $\mathrm{CH}_{4}$ (Saunois et al., 2020). Considering fossil fuel emissions alone, $68 \%$ of the emissions are linked to OG, while the rest are associated with coal mining. Emission of $\mathrm{CH}_{4}$ arises at each step from the production site to the consumption site. For the oil industry, methane emissions occur essentially as indirect emissions, i.e., as venting or incomplete combustion during flaring and during transport and refining (IEA, 2020). For the gas industry, emission of $\mathrm{CH}_{4}$ occurs at all stages of the life cycle as fugitive emissions (leaks from valves, connectors, and compressors and intentional venting) but also as incomplete combustion during flaring (GIE-MARCOGAZ, 2019). Alvarez et al. (2018) found that in the United States a large fraction of the net emission is associated with production, transport and processing.

Large uncertainties remain that are associated with the magnitude and spatial and temporal distribution of $\mathrm{CH}_{4}$ sources (Saunois et al., 2020). After a pause between 2000 and 2007, $\mathrm{CH}_{4}$ in the atmosphere has resumed its increase. Constraints from current available observations on the respective contribution to its sources and sinks do not allow a definitive explanation of this pattern (Saunois et al., 2017, 2020; Turner et al., 2019; Nisbet et al., 2020). Schwietzke et al. (2016) highlighted the strong underestimation of OG emissions in current inventories (see also Saunois et al., 2020, and references therein). Based on ice core ${ }^{13} \mathrm{CH}_{4}$ measurements, Hmiel et al. (2020) found that fossil fuel methane sources could be underestimated by as much as $25 \%-40 \%$. The largest uncertainty that remains associated with $\mathrm{CH}_{4}$ emissions is found during the extraction of $\mathrm{OG}$, with global estimates ranging from 46 to $98 \mathrm{MtCH}_{4} \mathrm{yr}^{-1}$ (Höglund-Isaksson, 2012). This uncertainty is critically related to the diversity of country-specific and site-specific emission factors used. In the US, emissions associated with OG production were underestimated by a factor 2 (Alvarez et al., 2018), which is mainly linked to underestimation in upstream (production) emissions. Furthermore, the spatial and temporal distribution of sources is poorly known. In the Barnett Shale area (USA), Zavala-Araiza et al. (2015) found that $10 \%$ of the OG facilities accounted for $90 \%$ of the emissions. Assessment of regional emission distributions can be provided by mobile measurements targeting facilities.

$\mathrm{CO}_{2}$ emissions linked to OG production and use represent $53 \%$ of total $\mathrm{CO}_{2}$ emissions over the period 2008-2017 (Le Quéré et al., 2018; not including land use change). Unlike $\mathrm{CH}_{4}, \mathrm{CO}_{2}$ emissions are to a large extent induced by fuel usage for energy consumption rather than production. In the near future, $\mathrm{CO}_{2}$ emissions are expected to continue increasing, driven by a strong demand in Asia (Jackson et al., 2019).

A large fraction of global OG extraction occurs in the eastern Mediterranean and Middle East region (EMME). The Middle East is the main crude oil production region (32\% of world total), with 24.16 million barrels per day, and $17,5 \%$ of global natural gas production, with 701.12 billion standard cubic meters produced in 2019 (OPEC, 2020). The main OG fields are located in the Arabian Gulf and neighboring countries, as well as in the Gulf of Suez and the Nile Delta. Gas fields have recently been discovered in the Levantine Sea. $\mathrm{CH}_{4}$ emissions reported by the EDGAR inventory for countries neighboring the Mediterranean Sea and Middle East amount to $16 \mathrm{MtCH}_{4} \mathrm{yr}^{-1}$ (6.0\% of global emissions) and $21 \mathrm{MtCH}_{4} \mathrm{yr}^{-1}$ (8.3\% of global emissions) (JanssensMaenhout et al., 2017), respectively. Across the different inventories reported in Saunois et al. (2020) for the Middle East, the spread represents $18 \%$ of the mean emission intensity, reflecting a significant uncertainty on country-level emissions. Increasing $\mathrm{CH}_{4}$ emissions in the Middle East and Africa have been proposed as a contribution to the post-2007 $\mathrm{CH}_{4}$ increase (McNorton et al., 2018).

According to the inventory data compiled by Friedlingstein et al. (2019), Mediterranean countries and Middle East $\mathrm{CO}_{2}$ emissions represent respectively $6.8 \%$ and $5.6 \%$ of global emissions. $\mathrm{CO}_{2}$ emissions for the EMME have increased from 662 to $831 \mathrm{MtC} \mathrm{yr}^{-1}$ over the period 20092018, essentially driven by fossil fuel use in Middle Eastern countries. This represent an annual growth rate of $2.5 \%$, which is significantly higher than the $1.3 \% \mathrm{yr}^{-1}$ increase rate of global emissions. $\mathrm{CO}_{2}$ emissions from the Middle East mostly arise from domestic consumption, while the emission transfers linked to international trade are negligible $\left(-2 \pm 7 \mathrm{MtC} \mathrm{yr}^{-1}\right.$; Peters et al., 2012). However, inventories may underestimate emissions from the main urban centers of the Middle East by a factor 2 (Yang et al., 2020).

The EMME region is a transitional zone between midlatitude climates and subtropical areas, located in the highpressure subtropical ridge (Lelieveld et al., 2012). The northern part of the EMME is under a westerly regime, with the eastern Mediterranean located in the outflow from European air masses in the lower troposphere (Lelieveld et al., 2002), while the southern part experiences trade winds. The EMME 
region includes a large amount of both desert and densely populated areas. Despite the region's important contribution to anthropogenic GHG emission, very few atmospheric measurements of the distribution of GHG are available in the area (Ricaud et al., 2018), limiting the possibility to reduce uncertainties in regional emissions rates. The Middle East remains undersampled, especially by the in situ surface networks (Ciais et al., 2010). It also offers fewer cloudy days than other midlatitude locations, thus enhancing the potential for passive satellite measurements (Yang et al., 2020).

What are the typical $\mathrm{CO}_{2}$ and $\mathrm{CH}_{4}$ mixing ratios around the Arabian Peninsula? What are the main drivers for the observed variability, and can we link this variability to sources? To what extent can we confirm or inform the inventories based on the measurements and more specifically the OG component of these inventories? This paper aims to obtain a better understanding the drivers of variability for these species in the area and to relate this variability to regional sources.

To address these questions, $\mathrm{CO}_{2}$ and $\mathrm{CH}_{4}$ mixing ratio measurements were performed during a ship cruise across the Mediterranean Sea, Red Sea and Arabian Gulf in the summer of 2017. Large-scale, shipborne measurements of $\mathrm{CH}_{4}$ and $\mathrm{CO}_{2}$ atmospheric concentrations have been previously performed for a wide variety of purposes, including measuring emissions from OG platforms (see, e.g., Yacovitch et al., 2020), assessing nation-wide emissions in the UK and Ireland (Helfter et al., 2019), and disentangling regional sources in the Arctic (Berchet et al., 2020).

Here we build on the work of Bourtsoukidis et al. (2019), who characterized light alkanes in relation to the various hydrocarbon sources in the region. We compare these results to a simulation of the anthropogenic component of $\mathrm{CO}_{2}$ and $\mathrm{CH}_{4}$ excess during the cruise using a Lagrangian particle dispersion model.

Section 2 details the AQABA (Air Quality and climate change in the Arabian Basin) campaign, as well as the measurement and modeling methodology. Section 3 presents measurement data and discusses how these data compare with simulations of $\mathrm{CH}_{4}$ and $\mathrm{CO}_{2}$ enhancements linked to anthropogenic activities.

\section{Methods}

\subsection{Campaign and platform}

The AQABA campaign took place in the summer of 2017 from 24 June to 3 September. The scientific purpose of the campaign was to investigate the atmospheric composition and chemical processes over the Arabian Basin (Pfannerstill et al., 2019; Wang et al., 2020; Bourtsoukidis et al., 2019, 2020; Tadic et al., 2020; Celik et al., 2020). The ship both departed from and returned to La Seyne-sur-Mer, near Toulon, France. Figure 1 shows the ship's route and calling ports.
The ship traveled through the Suez Canal and the Red Sea, then around the Arabian Peninsula and through the Arabian Gulf (also called the Persian Gulf) to Kuwait, where it anchored for $3 \mathrm{~d}$ (from 31 July to 3 August) at the port. The ship eventually returned and reached La Seyne-sur-Mer by approximately the same route on 2 September. Several calls occurred at various ports on the way. The ship used was the R/V Kommandor Iona, a UK-based, $76 \mathrm{~m}$ long dynamic positioning research and survey vessel. The mean speed of the vessel during the campaign was $3.4 \pm 1.8 \mathrm{~m} \mathrm{~s}^{-1}$.

\subsection{Measurements}

To minimize contamination of measurements by the ship's own emissions, the measurement inlet for $\mathrm{CO}_{2}$ and $\mathrm{CH}_{4}$ was located at the front of the ship, $15 \mathrm{~m}$ above sea level. Air was drawn through $15 \mathrm{~m}$ of Synflex tubing using a $2 \mathrm{~L} \mathrm{~min}^{-1}$ flush pump to prevent degradation of the system response time. The $\mathrm{CO}_{2}$ and $\mathrm{CH}_{4}$ mole fractions were measured in situ using a cavity ring-down spectroscopy analyzer (Picarro G2401; Santa Clara, USA) located in an air-conditioned container on the front deck. CO measurements were also collected. The air was not dried prior to analysis, and water vapor effects on $\mathrm{CO}_{2}$ and $\mathrm{CH}_{4}$ were determined specifically for this instrument and corrected (Hazan et al., 2016). A filter and a peristaltic pump ensured that no dust or liquid water entered the analyzer. Four different calibration cylinders of compressed air bracketing typical ambient concentrations were injected into the analyzer before departure, every $15 \mathrm{~d}$ during the trip and upon return to Toulon for calibration and quality assurance. Calibration gases were prepared in Luxfer aluminum cylinders. Calibration gas concentrations ranged between $377.63 \pm 0.01 \mathrm{ppm}$ and $474.84 \pm 0.01 \mathrm{ppm}$ for $\mathrm{CO}_{2}$, between $1791.8 \pm 0.1$ and $2791.0 \pm 0.2 \mathrm{ppb}$ for $\mathrm{CH}_{4}$, and between $127 \pm 1$ and $346 \pm 1 \mathrm{ppb}$ for $\mathrm{CO}$. The injection sequence consisted of four 20 min injections of each of the four gases. An additional target gas of ambient concentration was injected twice daily to assess measurement accuracy. Precision of the G2401 (expressed as continuous measurement repeatability) is typically better than $0.03 \mathrm{ppm} \mathrm{CO} 2,0.3 \mathrm{ppb} \mathrm{CH}_{4}$ and $8 \mathrm{ppb} \mathrm{CO}$ (Yver-Kwok et al., 2015). Calibrations were quite stable and consistently exhibited a within-run standard deviation of $0.03 \mathrm{ppm} \mathrm{CO}_{2}$, $0.3 \mathrm{ppb} \mathrm{CH}_{4}$ and $10 \mathrm{ppb} \mathrm{CO}$ with little change during the trip. The data have been processed and quality-controlled following ICOS (Integrated Carbon Observing System) standard procedure (Hazan et al., 2016), including the propagation of the calibration- and threshold-based filters. The concentrations measured from calibration cylinders between two calibration sequences show a mean drift of $0.05 \mathrm{ppm}$ and $0.5 \mathrm{ppb}$ $\mathrm{CH}_{4}$, significantly below the drifts typically observed at fixed observatories (Hazan et al., 2016). Target injections showed a small residual bias (after calibration) below $0.05 \mathrm{ppm} \mathrm{CO}_{2}$ and $0.3 \mathrm{ppb} \mathrm{CH}_{4}$. The measured target values for $\mathrm{CO}$ vary 


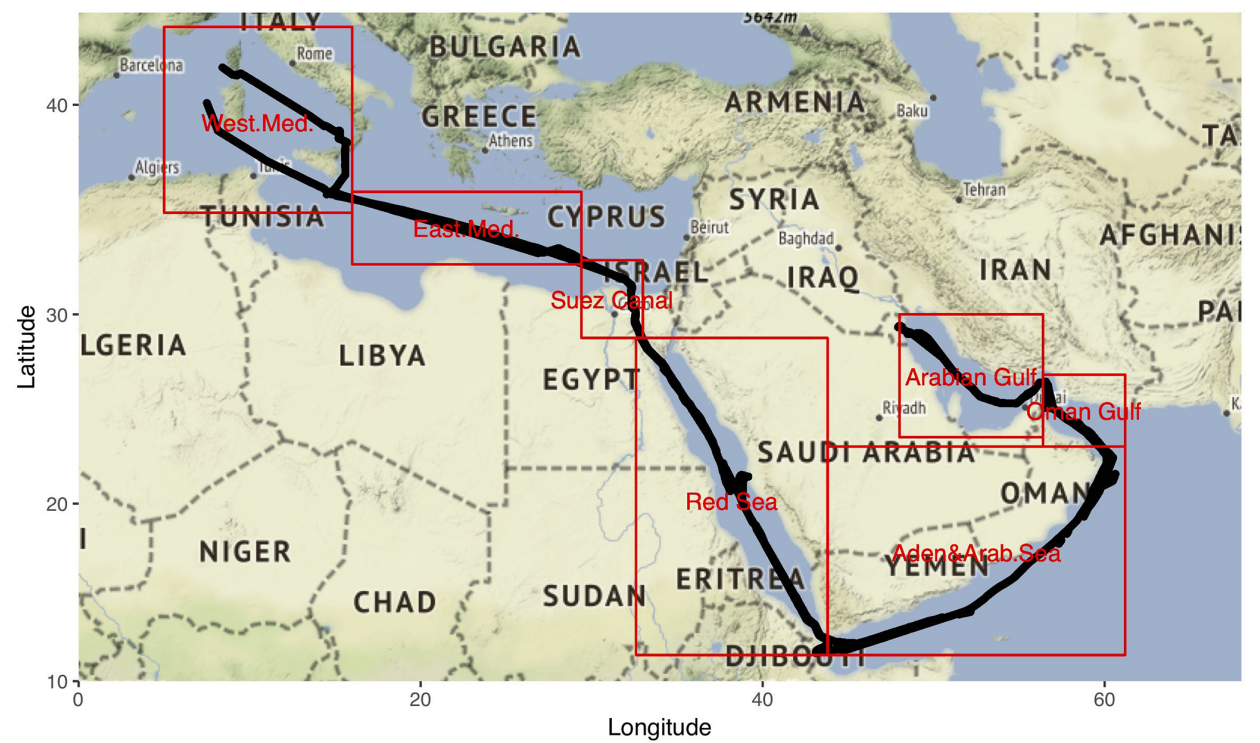

Figure 1. Ship track during the campaign. Regional limits are indicated. Background map: () OpenStreetMap contributors 2021. Distributed under the Open Data Commons Open Database License (ODbL) v1.0.

within $\pm 10 \mathrm{ppb}$ SD. The processed data are reported as $1 \mathrm{~min}$ averages.

Alkanes were measured using a gas chromatographyflame ionization detector (GC-FID; Bourtsoukidis et al., 2019). GC-FID sampling intervals were 10-30 min, with uncertainties ranging between $5 \%$ and $10 \%$. A detailed description of the GC-FID measurements can be found in Bourtsoukidis et al. (2019).

Meteorological parameters such as wind speed and direction, pressure, temperature, and GPS position and course were acquired from a meteorological station (Shipborne European Common Automatic Weather Station, EUCAWS) at the starboard side of the front deck of the ship.

\subsection{Stack contamination data filter}

As the sampling inlet was situated at the front of the boat, measurements can be occasionally influenced by the ship's stack emissions. We assume that this influence mainly depends on the relative wind direction, where a tailwind is likely to bring smoke from the boat's chimney back onto the instrument and thus contaminate the measurements. We flagged $1 \mathrm{~min}$ measured concentrations using a binary index that indicated a possible presence or absence of stack contamination as in Tadic et al. (2020). Different values of angle sector around the stern were tested to filter data using relative wind direction and speed. A total of $16 \%$ of the data were flagged as potentially contaminated by the ship and not considered in the following analysis unless specified otherwise.

\subsection{Lagrangian modeling}

Atmospheric transport was investigated using the FLEXible PARTicle dispersion model (FLEXPART) v9 Lagrangian particle dispersion model (Pisso et al., 2019) in receptororiented mode (Seibert and Frank, 2004). FLEXPART calculates the trajectories of a large number of tracer particles using the mean winds interpolated from the analysis fields plus random motions representing turbulence (Stohl and Thomson, 1999). Results presented here use European Centre for Medium-Range Weather Forecasts (ECMWF) analysis fields at $1^{\circ}$ resolution. Here, the backward method is used to analyze transport pathways from source regions to the receptor position. Each simulation consists of 10000 particles released every hour. Released particles were followed up to $14 \mathrm{~d}$ backward in time. Potential emission sensitivity is considered when particles reside below the boundary layer height as retrieved from the ECMWF analysis. Potential emission sensitivities are then convolved with gridded surface fluxes from emission inventories to simulate mixing ratios at the ship position during the cruise.

\subsection{Emission inventories}

For simplicity, our simulation uses surface emissions of $\mathrm{CO}_{2}$ and $\mathrm{CH}_{4}$ that include only anthropogenic emissions. Data are taken from the Emission Database for Global Atmospheric Research (EDGAR) v4.3.2 for the year 2012 (JanssensMaenhout et al., 2017, 2019). EDGAR estimates country total emissions for a variety of species including $\mathrm{CO}_{2}$ and $\mathrm{CH}_{4}$ based on international emission factors and activity data. Maps are eventually generated at a resolution of $0.1^{\circ} \times 0.1^{\circ}$ according to spatial proxies (see Fig. A1 for $\mathrm{CH}_{4}$ and Fig. A2 
for $\mathrm{CO}_{2}$ in Appendix A). For example, for fossil fuels exploitation, spatial proxies combine observed flaring and cartography of infrastructures. Our FLEXPART simulations calculate contributions detailed by sector and by country following the typology of the EDGAR database.

The Evaluating the Climate and Air Quality Impacts of Short-Lived Pollutants (ECLIPSE) baseline version CLE 5a (Höglund-Isaksson, 2012) is also used for comparative simulations of $\mathrm{CH}_{4}$ using FLEXPART $\left(\mathrm{CO}_{2}\right.$ is not provided as gridded data). ECLIPSE is derived from the GAINS model used for scenario analysis. ECLIPSE maps emissions at a resolution of $0.5^{\circ} \times 0.5^{\circ}$ according to spatial proxies that are different from EDGAR.

\section{Results and discussion}

\subsection{Spatial distribution of $\mathrm{CH}_{4}$ and $\mathrm{CO}_{2}$ along the cruise}

Figure 2 shows the concentrations observed during the two legs of the cruise. GPS data acquisition was missing in part of the western Mediterranean, and therefore parts of the data are not shown on the map. Figure 3a shows the measured $\mathrm{CH}_{4}$ mixing ratios statistics for each region during the cruise, excluding data influenced by the ship's own exhaust and data acquired when the ship is at rest. Median values in the western and eastern Mediterranean were $1903 \mathrm{ppb}$ (interquartile range, IQR, 1896-1907 ppb) and 1906 ppb (IQR 1879$1929 \mathrm{ppb}$ ), respectively, but significant differences were observed for each region between the two legs. For the eastern Mediterranean, Leg 1 median $\mathrm{CH}_{4}$ concentration is $1878 \mathrm{ppb}$ under a general northern wind influence, whereas Leg 2 median is $1929 \mathrm{ppb}$ with a generally southern wind. Closer to the Suez Canal, wind comes more generally from the south. The Gulf of Aden, the Arabian Sea and the Gulf of Oman were markedly lower in $\mathrm{CH}_{4}$, suggesting a different air mass origin. This is confirmed by a back-trajectory analysis using the FLEXPART model, showing a markedly different regional pattern in sensitivity in particle residence time in the boundary layer over Ethiopia, Somalia and the surrounding ocean (Fig. A3a). This is also consistent with the very low total $\mathrm{OH}$ reactivity observed in the area during the campaign (Pfannerstill et al., 2019). Wind direction in this area is mostly parallel to the ship track.

Figure $3 \mathrm{~b}$ shows the $\mathrm{CO}_{2}$ mixing ratio statistics for each region and each leg observed during the campaign. For each area, $\mathrm{CO}_{2}$ concentrations were higher during Leg 1 compared to Leg 2, likely reflecting hemispheric-scale drawdown in $\mathrm{CO}_{2}$ associated with uptake by Northern Hemisphere vegetation (see, e.g., Ramonet et al., 2010). The highest median concentrations are observed in the Arabian Gulf (410.27 ppm, IQR 407.16-415.36 ppm), whereas the lowest concentrations were encountered in August over the eastern Mediterranean, with 403.30 ppm (IQR 399.12-407.64 ppm), which was the closest value to the Mace Head mean mixing ratio in July and August. Ramonet et al. (2010) proposed that the minor changes in concentrations differences observed over eastern Europe compared to the marine baseline are due to biospheric uptake in Europe being offset by anthropogenic (fossil fuel) emissions along air mass pathways. Here, air mass origin is over eastern Europe's boundary layer over the previous $10 \mathrm{~d}$ according to FLEXPART back-trajectories (Fig. A3b).

The median mixing ratio of $\mathrm{CO}_{2}$ over the Aden and Arabian Sea are comparable to Red Sea and Mediterranean values, contrary to $\mathrm{CH}_{4}$ where mixing ratios were distinctly lower. $\mathrm{CO}_{2}$ mixing ratios do, however, exhibit a much lower variability (interquartile range) compared to other regions.

In the remainder of this paper, enhancements of $\mathrm{CH}_{4}$ and $\mathrm{CO}_{2}$ are defined as excess concentrations over a background that is defined for each region and each leg, according to Eq. (1).

$$
\Delta X=[X]-[X]_{\text {background }}
$$

The background is defined for the whole campaign as the 10 th percentile of measured mole fractions.

\subsection{Significance of fugitive sources based on light alkane measurements}

In this section we investigate the origin of $\mathrm{CH}_{4}$ enhancements in the regions where the highest median mixing ratio were observed. These regions, the Arabian Gulf, the Suez Canal and the Red Sea, are all areas where both offshore and onshore OG exploration are important (Fig. 4). Although the ship's track did not target specifically offshore platforms, the cruise collected a significant amount of strong $\mathrm{CH}_{4}$ enhancements coinciding with crossing of offshore platforms. Bourtsoukidis et al. (2019) showed that emissions from OG were significant contributions to non-methane hydrocarbons measured during the cruise over several areas around the Arabian Peninsula. According to the EDGAR emission inventory (Janssen-Maenhout et al., 2017), the OG industry is responsible for up to $80 \%$ of $\mathrm{CH}_{4}$ emissions in the Middle East. Local enhancements of mixing ratio in air masses are typically linked to local or regional sources. The most likely origin of the high $\mathrm{CH}_{4}$ and $\mathrm{CO}_{2}$ concentrations over the Arabian Gulf and the Suez Canal is anticipated to be anthropogenic emissions. In this section we investigate the origin of $\mathrm{CH}_{4}$ enhancements by assessing their correlation with alkanes measured onboard the ship. In this analysis, all $\mathrm{CH}_{4}$ and $\mathrm{CO}_{2}$ measurements are averaged specifically over the sampling interval of the GC-FID.

Over the whole campaign, we observed a significant but small correlation between $\mathrm{CH}_{4}$ and $\mathrm{C}_{2} \mathrm{H}_{6}(r=0.386$, $p<10^{-15}$ ). The highest $\mathrm{C}_{2} \mathrm{H}_{6}$ concentrations are observed over the Arabian Gulf (Fig. 5). In this region, a significant correlation between $\mathrm{C}_{2} \mathrm{H}_{6}$ and $\mathrm{CH}_{4}(r=0.332$, $p=0.004)$ was derived, with a region-wide regression slope 

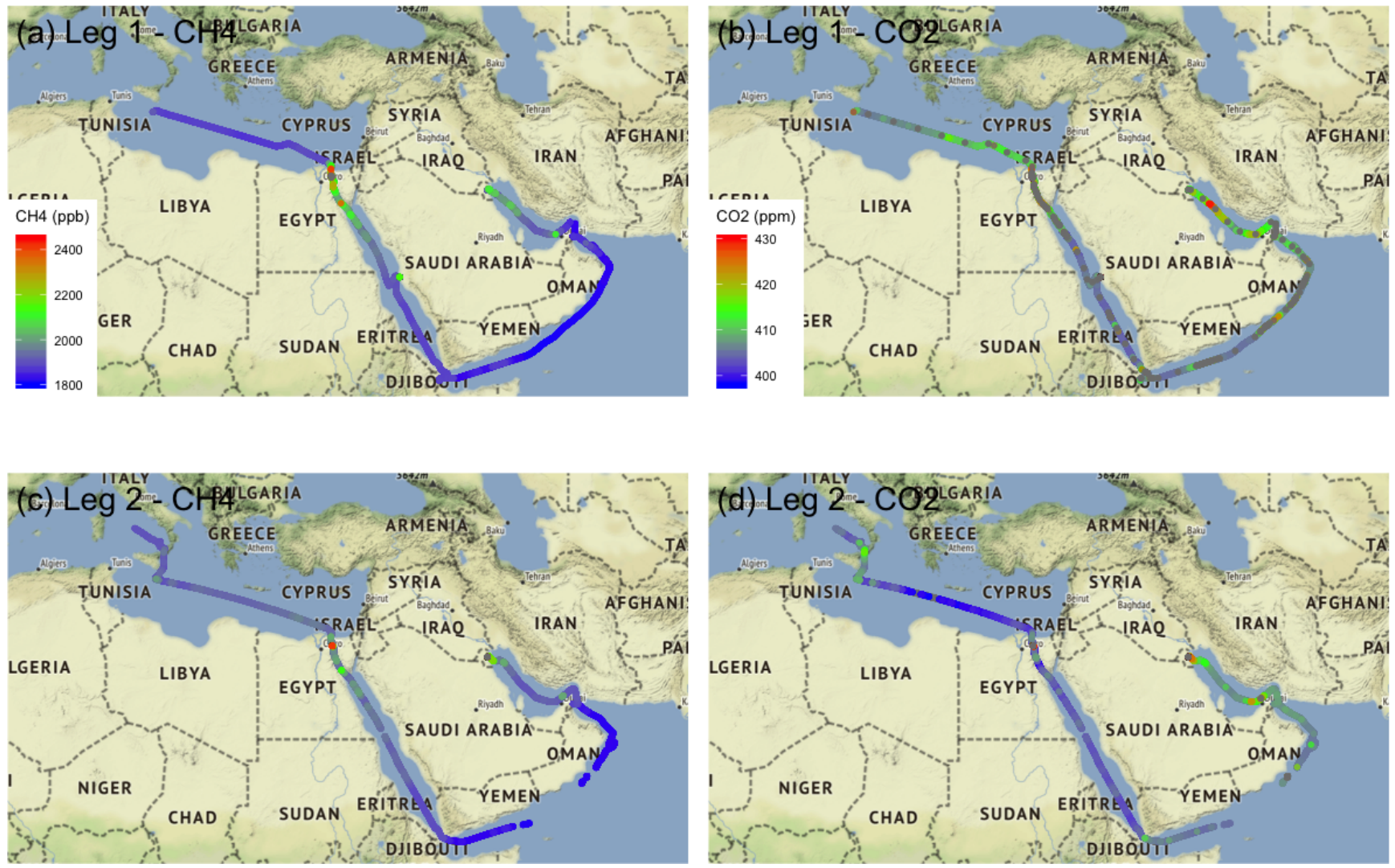

Figure 2. Measurements of $\mathrm{CH}_{4}(\mathbf{a}, \mathbf{c})$ and $\mathrm{CO}_{2}(\mathbf{b}, \mathbf{d})$ collected during Leg 1 from Toulon to Kuwait between 24 June and 31 July 2017 (a, b) and Leg 2 from Kuwait to Toulon between 3 August and 2 September 2017 (c, d). Background map: () OpenStreetMap contributors 2021. Distributed under the Open Data Commons Open Database License (ODbL) v1.0.

of $0.062 \mathrm{ppbppb}^{-1}$. Similarly, $\mathrm{CH}_{4}$ was correlated with propane $(r=0.356, p=0.002)$ and the sum of $i$-butane and $n$-butane $(r=0.360, p=0.002) . \mathrm{CH}_{4}$ was also correlated with $\mathrm{CO}_{2}\left(r=0.53, p=2 \times 10^{-12}\right)$ and $\mathrm{CO}(r=0.76$, $p<10^{-15}$ ) in the Arabian gulf, suggesting that $\mathrm{CH}_{4}$ variability is dominated by emissions from OG activities colocated with combustion sources. Flaring may typically contribute to such an emission profile. However, $\mathrm{CO}_{2}$ showed no significant correlation with any of the three alkanes mentioned above. This suggests that $\mathrm{CO}_{2}$ variability in the area is dominated by other factors than $\mathrm{OG}$ sources.

Over the Red Sea, $\mathrm{CH}_{4}$ enhancements of about $200 \mathrm{ppb}$ above background have been observed. A clear correlation between $\mathrm{C}_{2} \mathrm{H}_{6}$ and $\mathrm{CH}_{4}\left(r=0.71, p<10^{-15}\right)$ is associated with a regression slope of $0.047 \mathrm{ppb} \mathrm{ppb}^{-1}$. No significant correlation is found for $\mathrm{CH}_{4}$ against $\mathrm{CO}_{2}(r=-0.08$, $p=0.1368)$ or $\mathrm{CO}\left(r=0.23, p=2 \times 10^{-15}\right)$.

For the Suez Canal area, the regression slope between $\mathrm{C}_{2} \mathrm{H}_{6}$ and $\mathrm{CH}_{4}$ is $0.006 \mathrm{ppbppb}^{-1}\left(r=0.75, p<10^{-15}\right)$. Strong correlations are found between $\mathrm{CH}_{4}$ and $\mathrm{CO}_{2}$ $\left(r=0.83, \quad p<10^{-15}\right)$ and $\mathrm{CH}_{4}$ and $\mathrm{CO} \quad(r=0.87$, $\left.p<10^{-15}\right)$. This indicates that combustion sources are strongly contributing to $\mathrm{CH}_{4}$ variability in the Suez Canal.
The air mass originates from the eastern Mediterranean and Egypt according to FLEXPART back-trajectory simulations (Fig. A3c). Differences in $\mathrm{C}_{2} \mathrm{H}_{6}$ to $\mathrm{CH}_{4}$ regression slopes between the Suez Canal and the Red Sea may therefore reflect either an aggregation of different OG emission sources or different fraction of $\mathrm{OG}$ in observed $\mathrm{CH}_{4}$ enhancements.

Ethane is a valuable proxy for fossil fuel emissions at the global scale and has provided evidence of the reduction of fossil fuel emission in the 2000s (Simpson et al., 2012). As a proxy at the site scale, it contributes to the separation of thermogenic and biogenic emissions (e.g., Rella et al., 2015; Assan et al., 2017; Lowry et al., 2020, Defratyka et al., 2021). However, the range of $\mathrm{C}_{2} \mathrm{H}_{6}: \mathrm{CH}_{4}$ ratio can be highly variable at regional scale, from emission site to site, and along the production chain. Measuring downwind of $>100$ offshore platforms in the Gulf of Mexico, Yacovitch et al. (2020) found $\mathrm{C}_{2} \mathrm{H}_{6}: \mathrm{CH}_{4}$ ratio ranging from $0.16 \%$ to $17 \%$. The gas associated with the Deepwater Horizon oil spill sampled in the hydrocarbon plume rising from the seafloor showed a $\mathrm{C}_{2} \mathrm{H}_{6}: \mathrm{CH}_{4}$ ratio between $8.1 \%$ and $8.3 \%$ (Reddy et al., 2012). This ratio depends on the temperature of formation of natural gas (Whitticar, 1994). The ratio can be further modified if a significant fraction of $\mathrm{CH}_{4}$ is emitted through flar- 

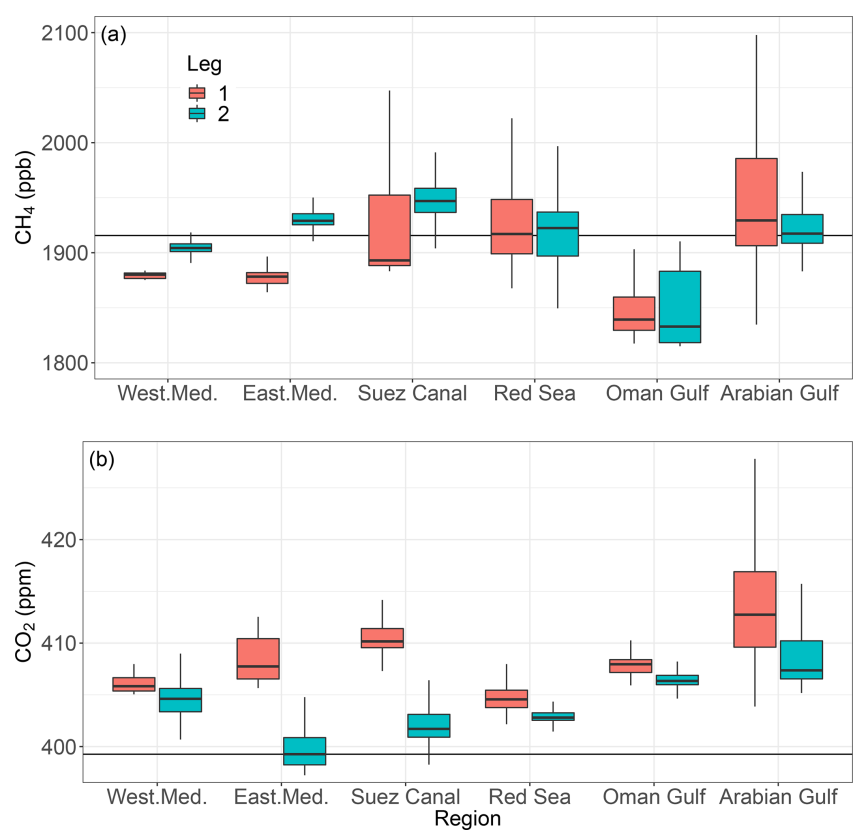

Figure 3. Methane (a) and carbon dioxide (b) mixing ratios observed during the cruise. See Fig. 1 for region definition. Data from when the ship was at rest or contaminated by the ship's own exhaust are excluded. The box plot shows the interquartile range $(25 \%-$ $75 \%$ ) and median values for each grouping of data. The bars extend to the lowest and highest values, (ignoring outliers beyond 1.5 times the interquartile range). The statistics of the two legs are represented separately. The horizontal black line is the mean methane mixing ratio at Mace Head, Ireland (NOAA), during July and August 2017.

ing, with different depletion during combustion (Yacovitch et al., 2020). Hence, due to its inherent variability from field to field, the $\mathrm{C}_{2} \mathrm{H}_{6}: \mathrm{CH}_{4}$ ratio alone is insufficient without additional constraints to quantify the relative contribution of $\mathrm{OG}$ to $\mathrm{CH}_{4}$ emissions at the regional scale.

Figure 6 shows the $i$-pentane to $n$-pentane ratio for selected regions. This ratio is another tracer of the contribution of natural gas, vehicle exhaust or fuel evaporation emissions to the atmospheric burden of alkanes and associated species (Gilman et al., 2013; Bourtsoukidis et al., 2019). For natural gas the ratio is expected to be 0.86 (indicated as a horizontal line in Fig. 6). Since the ratio is conserved against oxidation by $\mathrm{OH}$ in the atmosphere, the tracer is conserved during atmospheric transport. Isomerization of oil after distillation is widely used to obtain gasoline with higher octane indices. This process results in a decreased $\mathrm{nC} 5$ concentration in gasoline and hence a higher $\mathrm{iC} 5 / \mathrm{nC} 5$ ratio in urban environments. In natural gas processing, pentane is part of the condensate separated from the commercial natural gas. In the Arabian Gulf, where the mean $\mathrm{CH}_{4}$ enhancement was $67 \mathrm{ppb}$ and the maximum was $255 \mathrm{ppb}$, the linear regression slope was found to be $0.939 \pm 0.023 \mathrm{ppb} \mathrm{ppb}^{-1}$. The mean ratio of the isomers was $1.00 \pm 0.12$, suggesting a clear dominance of sources linked to OG extraction and production.

\subsection{Photochemical age and remoteness of sources}

Alkanes have different atmospheric lifetimes, and (if species are co-emitted at the same time and with a known emission ratio) measured changes in their ratios can help trace the photochemical age of an air mass (Purvis et al., 2003), and hence they can provide an indication of a transport time from the source to the receptor. The ratio of species is less sensitive to dilution and air mass mixing than the concentration of individual species. Transport time and photochemical age correlate particularly well for lighter alkanes (Parrish et al., 2007). For the AQABA campaign, Pfannerstill et al. (2019) used decreases in the $\left[\mathrm{C}_{3} \mathrm{H}_{6} \mathrm{O}\right] /\left[\mathrm{C}_{3} \mathrm{H}_{8}\right]$ ratio and simultaneous increases in the toluene / benzene ratio in the Arabian Gulf as an indicator of nearby sources. Wang et al. (2020) analyzed the mismatch between the toluene / benzene measured ratio and emission ratio. Here we compare, for several regions, (1) the decorrelation that occurs between $\mathrm{CH}_{4}$ and light alkanes (propane and pentane) during early photochemical aging due to differences in kinetic rates against $\mathrm{OH}$ and (2) the photochemical age of air masses exhibiting significant correlations between propane and pentane.

Propane $\left(\mathrm{C}_{3} \mathrm{H}_{8}\right)$ has a lifetime of ca. $5.5 \mathrm{~d}$, while pentane $\left(\mathrm{C}_{5} \mathrm{H}_{12}\right)$ has a lifetime of $0.5-1 \mathrm{~d}$ with respect to $\mathrm{OH}$ radical oxidation (Bourtsoukidis et al., 2019). Figure 7 shows scatterplots of $\mathrm{CH}_{4}$ to propane and pentane (the latter as the sum of $n$-pentane and $i$-pentane). Correlation between $\mathrm{CH}_{4}$ and propane is relatively homogeneous across regions, albeit with very different slopes. For the Arabian Gulf the correlation coefficient is $r=0.37$, for the Gulf of Oman it is $r=0.46$, and for the Suez Canal we obtain $r=0.50$. The correlation of $\mathrm{CH}_{4}$ to pentane is more contrasted. For the Arabian Gulf and Suez Canal the correlation coefficient remains significantly high $(r=0.40$ and $r=0.67$, respectively), which is comparable to the propane to $\mathrm{CH}_{4}$ correlations. The significant correlations suggest that the air mass is affected by emissions with constant ratios, and hence there is a regional signature of local sources. This corroborates the results of Wang et al. (2020), who found limited departure between the measured ratio and emission ratio for these two regions. In contrast, in the Gulf of Oman there is no correlation between $\mathrm{CH}_{4}$ and propane $(r=0.003)$. This suggests that high $\mathrm{CH}_{4}$ concentrations observed in the Arabian Gulf and Suez Canal are mainly determined by relatively nearby sources co-emitting $\mathrm{CH}_{4}$, pentane and propane. This approach suggests that excess $\mathrm{CH}_{4}$ observed over the Gulf of Oman is emitted from remote sources or without co-emission of these species.

As a next step we evaluate the average photochemical age of air masses for the Suez Canal and Arabian Gulf regions. For that purpose, we examine, at the regional scale, the change in measured propane to $(n+i)$-pentane ratio relative to the initial emission ratio. We follow the definition of photochemical age against $\mathrm{OH}$ defined in Parrish et al. (2007), given here in Eq. (2) below. 


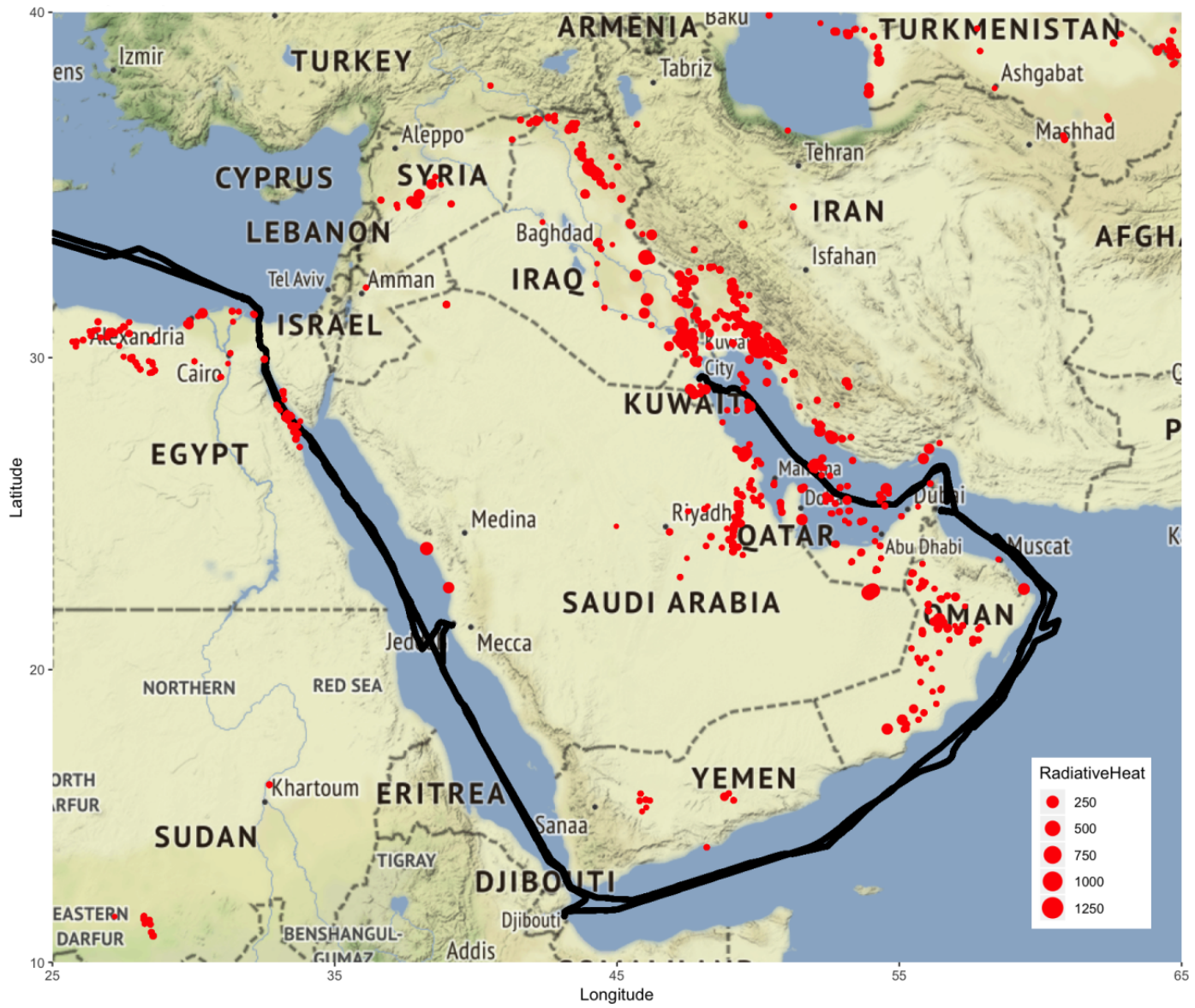

Figure 4. Ship track superimposed with flaring sources detected by NASA/NOAA Visible Infrared Imaging Radiometer Suite active in 2017. Dot size is proportional to the highest observed radiative heat (in MW), which in turn is related to the volume of gas flared (Elvidge et al., 2016). Flaring occurs mostly at the upstream production sites and is therefore a proxy for the presence of extraction and production sites. Flaring spots retrieved from http://skytruth.org (last access: 16 April 2019). Background map: () OpenStreetMap contributors 2021. Distributed under the Open Data Commons Open Database License (ODbL) v1.0.

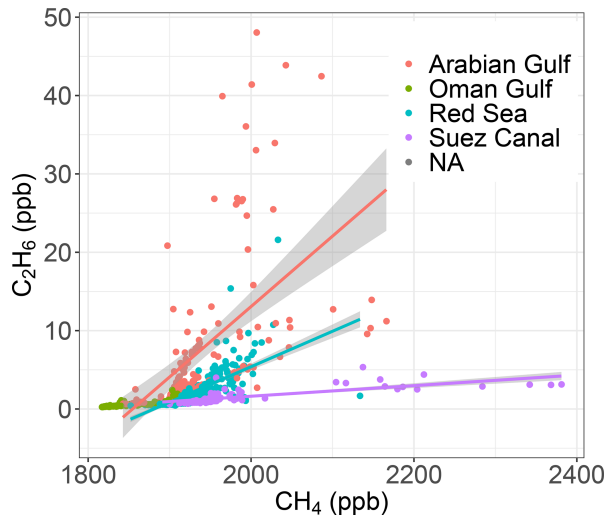

Figure 5. Scatterplot of ethane and methane for the Gulf of Oman, Arabian Gulf, Red Sea and Suez Canal. The regression line and associated $95 \%$ confidence interval are plotted for the Arabian Gulf, Red Sea and Suez Canal regions.

$$
\begin{aligned}
t_{\mathrm{a}}\langle[\mathrm{OH}]\rangle & =\int_{t=t_{\mathrm{E}}}^{t_{\mathrm{R}}}[\mathrm{OH}] \mathrm{d} t \\
& =-\frac{1}{\left\langle k_{A}-k_{B}\right\rangle}\left\{\ln \left(\frac{[A]}{[B]}\right)-\ln \left(\frac{\left[A_{0}\right]}{\left[B_{0}\right]}\right)\right\},
\end{aligned}
$$

where $t_{\mathrm{a}}$ is the average photochemical age against $\mathrm{OH}$, $\langle[\mathrm{OH}]\rangle$ is the mean concentration of $\mathrm{OH}$ along the pathway, $t_{\mathrm{E}}$ refers to time of emission and $t_{\mathrm{R}}$ time of reception, $A$ and $B$ are the two species propane and pentane, and $A_{0}$ and $B_{0}$ are the initial ratio at the time of emission. We evaluate the mean ratio of concentration between species at the regional scale as the regression slope between the two species. The regression slope of pentane against propane is $0.149 \mathrm{~mol} \mathrm{~mol}^{-1}$ for the Suez Canal and $0.378 \mathrm{~mol} \mathrm{~mol}^{-1}$ for the Arabian Gulf. The ratio of species at the time of origin is approximated by the emission ratio from the EDGAR v4.3.2 inventory for volatile organic compounds 

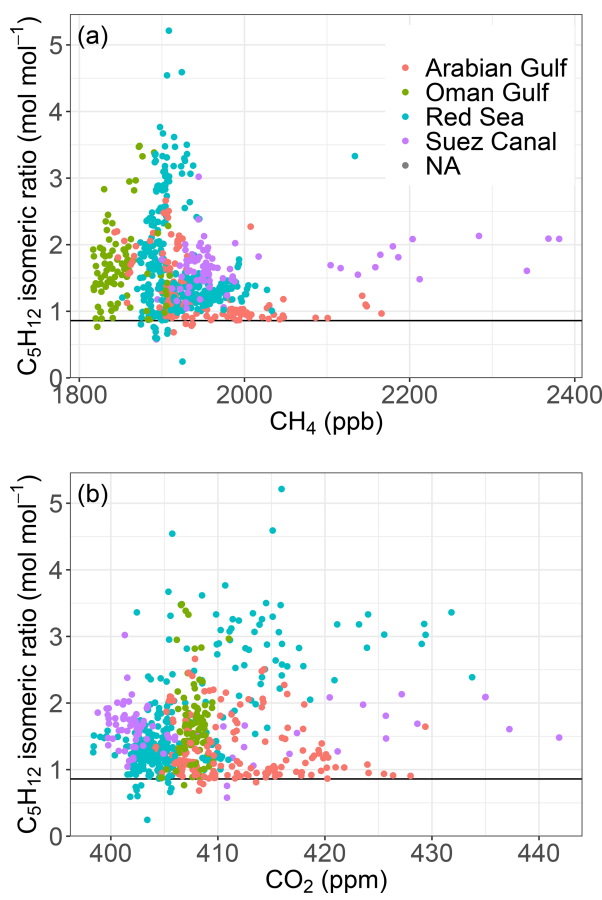

Figure 6. Scatterplot of $i$-pentane / $n$-pentane and methane (a) and $i$-pentane $/ n$-pentane and $\mathrm{CO}_{2}$ (b) for the Oman Gulf, Arabian Gulf, Red Sea and Suez Canal. The value of the $i$-pentane to $n$-pentane ratio associated with oil and gas emission (0.86) is drawn as a horizontal line in the two panels.

(Huang et al., 2017). The inventory-based emission ratio is $0.460 \mathrm{~mol} \mathrm{~mol}^{-1}$ for the total emissions of Middle East countries and $0.435 \mathrm{~mol} \mathrm{~mol}^{-1}$ for Egypt. Overall this value varies within a limited span (ranging from $0.347 \mathrm{~mol} \mathrm{~mol}^{-1}$ for Kuwait to $0.682 \mathrm{~mol} \mathrm{~mol}^{-1}$ for Iran) across countries with significant emissions of these two species. We use kinetic rate coefficients as reported by Pfannerstill et al. (2019, their Table S1) and assume a mean $\mathrm{OH}$ concentration of $7.5 \times 10^{6} \mathrm{~mol} \mathrm{~cm}^{-3}$ following Wang et al. (2020). This approach yields a photochemical age for our air masses of $1.5 \mathrm{~d}$ for the Suez Canal and $0.28 \mathrm{~d}$ for the Arabian Gulf. At a median true wind speed of $3.9 \mathrm{~m} \mathrm{~s}^{-1}$ (as observed over the Arabian Gulf and over the Suez Canal), this suggests that sources are distant on average by 206 and $38 \mathrm{~km}$, respectively, for the Suez Canal and the Arabian Gulf.

However, this crude approach to the assessment of remoteness of sources of $\mathrm{CH}_{4}$ excesses in the Arabian Gulf and the Red Sea is not sufficient on its own and should be compared to tagged transport simulations.

\subsection{Tagged tracer simulation of anthropogenic methane}

We simulated the anthropogenic excess mixing ratio of $\mathrm{CH}_{4}$ and $\mathrm{CO}_{2}$ using FLEXPART and the EDGAR emission inventory. Figure 8 shows a comparison of simulated excess
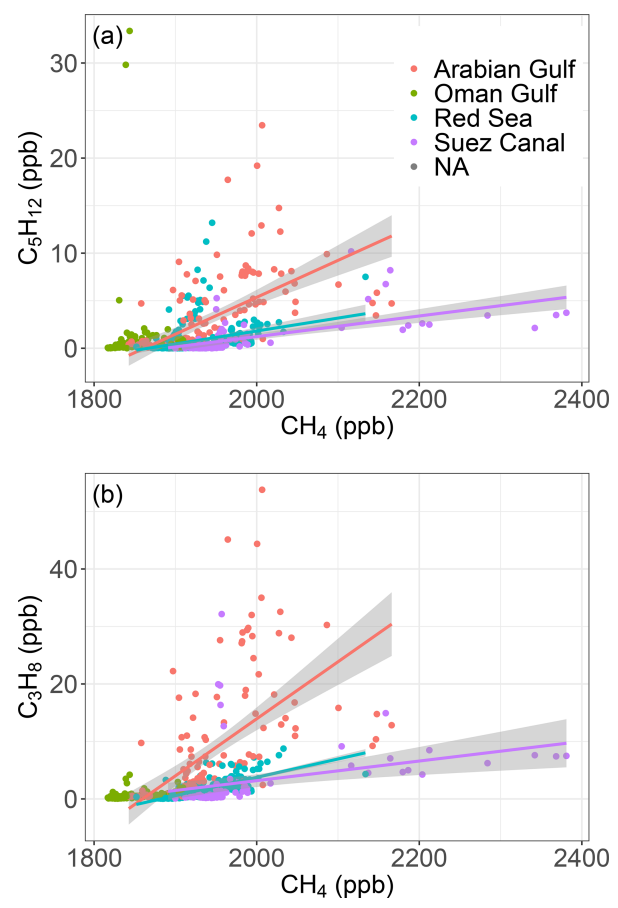

Figure 7. Scatterplot of (a) pentane and (b) propane against methane for the Gulf of Oman, Arabian Gulf, Red Sea and Suez Canal. The regression line and associated uncertainty are plotted for each of these four regions.

$\mathrm{CH}_{4}$ time series at the receptor position and $\Delta \mathrm{CH}_{4}$ measured from the ship. The model reproduces the region-wise variability of the signal reasonably well. In the distinctly low $\mathrm{CH}_{4}$ concentration area over the Gulf of Aden and Arabian Sea, the model appropriately simulates enhancements close to zero. In the high-concentration area of the Arabian Gulf (from 28 July to 6 August) the model captures the presence of strong enhancements, despite being poorly positioned along the ship track. Over the Red Sea, the model captures the variability correctly. The regional baseline of the signal is, however, challenging to reproduce with the model since measurements are expressed as excess $\mathrm{CH}_{4}$ with a background calculated by leg and across all regions. This sharply highlights the difference between the low-concentration areas (Gulf of Aden and Arabian Sea) versus the other areas more influenced by anthropogenic emissions.

The OG emissions contribute to $35 \%$ of the simulated excess $\mathrm{CH}_{4}$ overall. Over the Arabian Gulf and Gulf of Oman, it accounts, respectively, for $81 \%$ and $63 \%$ of $\mathrm{CH}_{4}$ excess on average, consistent with the regional emission pattern and alkane measurements presented above. Over the Red Sea, OG emission of $\mathrm{CH}_{4}$ explains $37 \%$ of the simulated variability on average. Waste management represents on average $27 \%$ of the simulated $\mathrm{CH}_{4}$ excess for the whole campaign. In the Arabian Gulf, waste management represents only $12 \%$ of $\mathrm{CH}_{4}$ variability. 


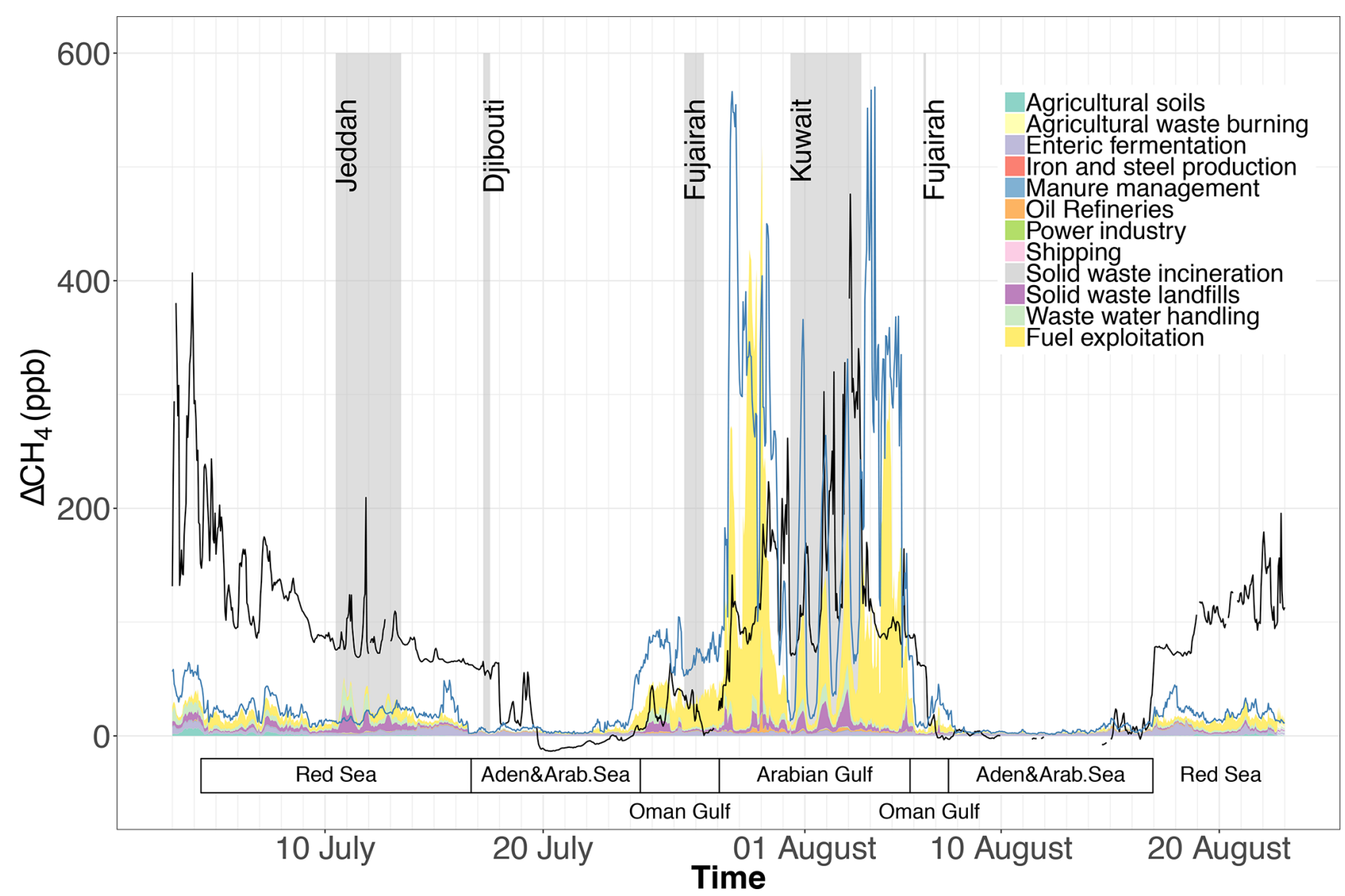

Figure 8. Comparison of simulated excess $\mathrm{CH}_{4}$ time series at the receptor position and hourly average $\Delta \mathrm{CH}_{4}$ measured from the ship (black line). All data at harbors are included. The simulation combines FLEXPART potential emission sensitivity and EDGAR inventory (stacked areas). The main source sectors are indicated using a color code. The potential emission sensitivity is also combined with the ECLIPSE inventory for comparison (blue line). The stops at each harbor are indicated as shaded gray areas, with the names of the harbors indicated at the top.

The observations at harbor locations (gray shading in Fig. 8) exhibit a strong diurnal pattern that is well reproduced by the model, probably due to the proximity of the land mass and the diurnal cycle of the atmospheric boundary layer development. However, the amplitude of the diurnal cycle is rather underestimated by the model, notably for the stop-over in Jeddah between 10 and 13 July. At harbors, the OG signal remains dominant, especially in Kuwait. The simulated share of waste management sources to the total $\mathrm{CH}_{4}$ enhancement is twice as much as that found over open sea. However, due to the proximity of sources within the inventory spatial resolution, the model may not fully resolve the ratio between these contributions. Closer to Kuwait, back-trajectories show a stronger sensitivity to potential sources in Iran.

The highest $\mathrm{CH}_{4}$ concentrations over the Arabian Gulf are mostly observed in its northern part, while the simulation predicts higher concentrations in the southern part, especially in the vicinity of the South Pars (North Dome) gas field. However, the $\mathrm{CH}_{4}$ enhancement observed in the immediate vicinity of this gas field is much lower than the simulated one. The model points to an "OG exploitation" source type in the northwestern half of the Arabian Gulf for the strongest $\mathrm{CH}_{4}$ enhancements observed. In a wide US survey of 8000 facilities, Lyon et al. (2016) found that super-emitter sites were 3 times more frequently associated to oil than the gas assets and that $90 \%$ of sources were from tank vents and hatches used in oil storage. Our study would suggest an underestimation of oil upstream emissions by the inventories and an overestimation of leak rates in the upstream natural gas industry.

Figure 9 shows the measured excess $\mathrm{CO}_{2}$ while navigating in the Gulf of Oman and the Arabian Gulf. The simulated excess is dominated by the power industry sector, accounting for most of the variability, with contributions from the oil refineries and oil transformation sectors and local maxima off the coast of United Arab Emirates. This area hosts the Jebel Ali oil refinery, which is dedicated to the production of liquefied petroleum gas, naphtha and a variety of fuel types, as well as the Takreer Abu Dhabi oil refinery, which is located further south (retrieved from https://www.industryabout. 


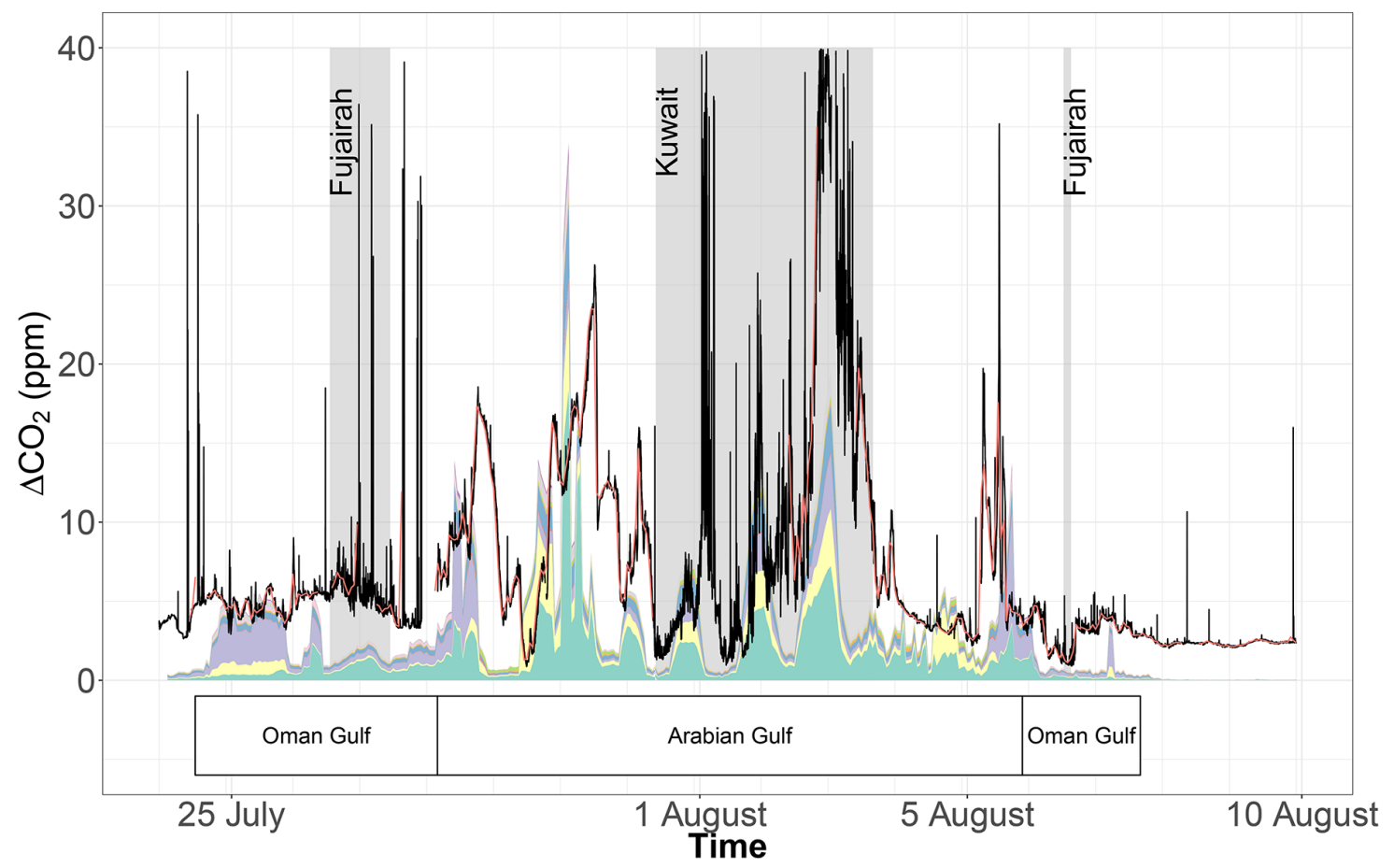

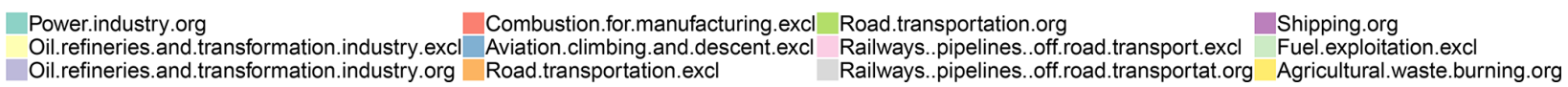

Figure 9. Comparison of simulated excess $\mathrm{CO}_{2}$ time series at the receptor position in the Gulf of Oman and Arabian Gulf and hourly average $\triangle \mathrm{CO}_{2}$ measured from the ship (black line). Flagged, hourly average data are shown in light red. The simulation combines FLEXPART potential emission sensitivity and the EDGAR inventory (stacked areas). The main source sectors are indicated using a color code. The stops at each harbor are indicated as shaded gray areas, with the names of the harbors indicated at the top.

com/arabian-peninsula-industrial-map, last access: 30 June 2021).

Figure 10 shows the contribution of countries or areas of origin to simulated $\mathrm{CH}_{4}$ in the Arabian Gulf during Leg 1, where emissions are dominated by fossil fuel exploitation (see discussion on alkanes above and simulation in Fig. 8). By tagging the simulated $\mathrm{CH}_{4}$ enhancements by source region, it is possible to link the contributions of source regions to the ability of the model to reproduce the observed signal.

Off the coast of Dubai and the United Arab Emirates (transect A-B in Fig. 10), the simulation is in good agreement with the observations and points to a strong contribution from the nearby state (United Arab Emirates) and the local offshore activities in the Arabian Gulf. The highest $\mathrm{CH}_{4}$ concentration of the section is measured (2109 ppb) within a thin plume lasting 15 min (labeled B in Fig. 10, 18:0518:20 UTC). The model successfully captures this enhancement with an average of $150 \mathrm{ppb}$ excess $\mathrm{CH}_{4}$, although in this case it is spread over $2 \mathrm{~h}$. It is simulated as coming mostly $(80 \%)$ from local offshore emissions (Arabian Gulf South in Fig. 10) while the ship is moving through the Fateh oil field off Dubai. Approaching the North Dome field off the coast of Qatar (point C, and during 29 July), however, $\mathrm{CH}_{4}$ is strongly overestimated by the model, with simulated en- hancements of more than $400 \mathrm{ppb}$ having no equivalent pattern in the measurement. In the model this strong enhancement is due to local offshore emissions (southern part of the Arabian Gulf) associated with the South Pars (North Dome) gas field. South Pars (North Dome) field is the largest gas field in the world and is shared between Iran and Qatar (Conti et al., 2016). In the northern part of the Arabian Gulf (transect from $\mathrm{C}$ to $\mathrm{D}$ ), significant $\mathrm{CH}_{4}$ enhancements are measured, and the model fails to reproduce these enhancements, although it suggests local emissions (northern Arabian Gulf and Kuwait) are dominant, consistent with the photochemical age of air masses (Sect. 3.3).

\subsection{Model-data comparison}

Can we confirm or verify the inventories based on the measurements? The entire dataset (excluding data flagged as contaminated and stationary measurements at harbors) has a correlation of $r=0.13$. The agreement improves during nighttime with $r=0.22$. Overall, the simulation represents the variability of $\mathrm{CH}_{4}$ well at the synoptic scale. The firstorder discrepancies arise from the difference in background between regions, since here the background used to offset the $\mathrm{CH}_{4}$ measurements is calculated for the whole cam- 


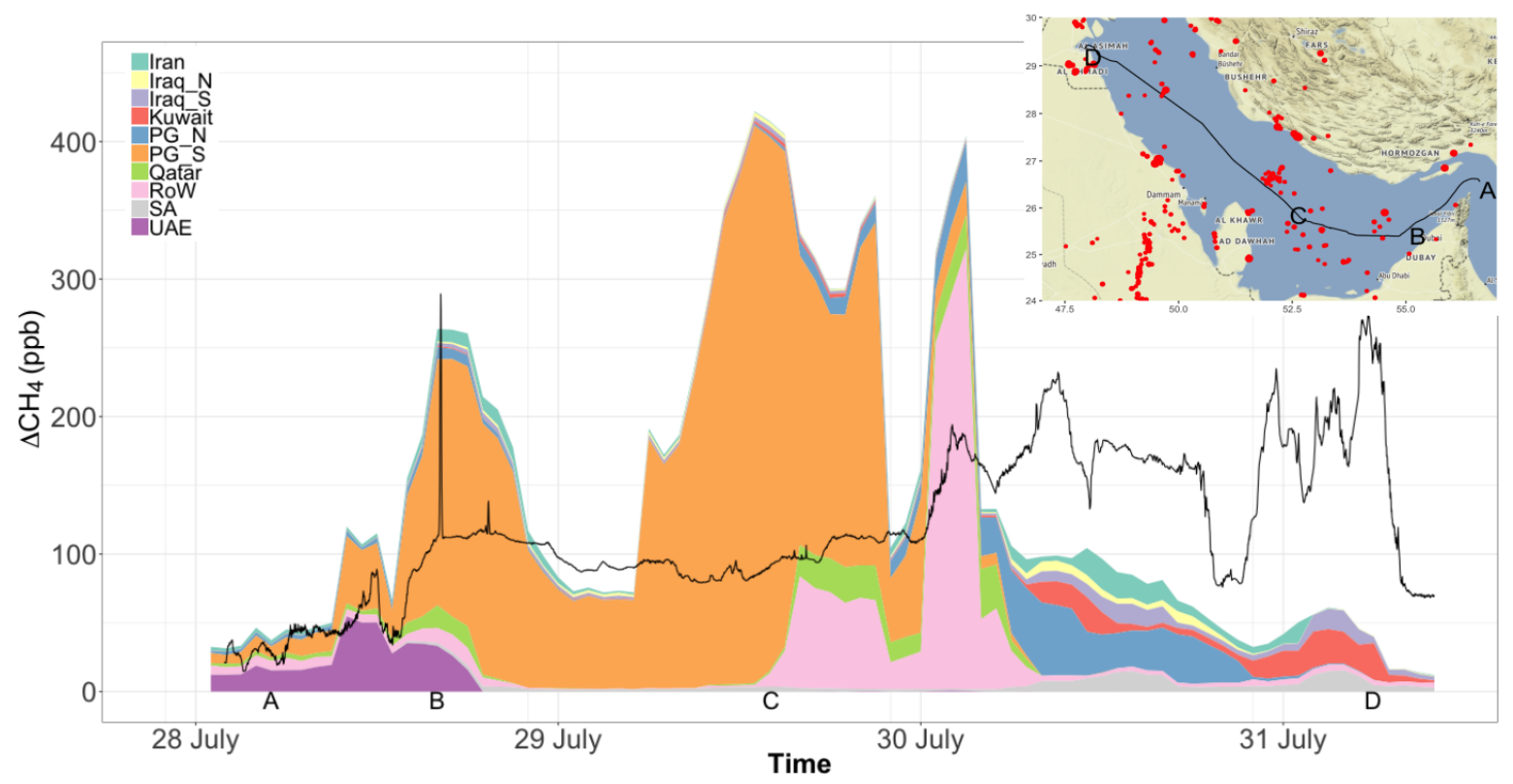

Figure 10. Simulation of $\Delta \mathrm{CH}_{4}$ by country of origin over the Arabian Gulf. The solid line shows the measured $\mathrm{DCH}_{4}$. The simulated excess $\mathrm{CH}_{4}$ is tagged and color coded by country or area of origin. The regions are indicated by the following abbreviations: Iraq_N is northern Iraq, Iraq_S is southern Iraq, PG_N is the northern half of the Persian (Arabian) Gulf, PG_S is the southern half of the Persian (Arabian) Gulf, RoW is the rest of the world, SA is Saudi Arabia, and UAE is the United Arab Emirates. The inset shows the trajectory of the ship corresponding to the simulation, and the labels A, B, C and D highlight points of the ship's route discussed in the main text. Red points correspond to flaring detected from space (see Fig. 4) at the time of the campaign. Inset background map: () OpenStreetMap contributors 2021. Distributed under the Open Data Commons Open Database License (ODbL) v1.0.

paign. While the measured $\Delta \mathrm{CH}_{4}$ is an excess over a predefined background, the simulated excess $\mathrm{CH}_{4}$ integrates anthropogenic surface sources during $14 \mathrm{~d}$ prior to reaching the receptor. Therefore, in order to compare these two quantities, the mismatch between the boundary conditions of the model (i.e., $\mathrm{CH}_{4}$ of the air mass prior to the $14 \mathrm{~d}$ before measurement) and the background defined for the measurement data introduces a varying offset. However, the simulated time series can be considered an indication of the geographical or sectoral origin of the observed excess mixing ratio.

Figure 11 provides a comparison of the fractional contribution of $\mathrm{OG}$ exploitation sources to simulated $\mathrm{CH}_{4}$ excess with the $i$-pentane to $n$-pentane ratio (see Sect. 3.2). We find that an exponential decrease model can fit the data with a significant correlation $r=-0.38\left(p<10^{-16}\right)$. This exponential model yields an estimated $i$-pentane to $n$-pentane ratio of 0.99 when the simulation fraction of OG is $100 \%$, whereas an absence of OG exploitation would yield a ratio of 1.84 . This confirms that the fraction of emissions linked to OG exploitation in the model is consistent with our expectations according to the isomeric ratio of pentane (Bourtsoukidis et al., 2019).

The inventory used for the simulation also integrates a large part of uncertainty in terms of intensity and location of the sources. To test the sensitivity to the emission inventory itself, we simulated $\mathrm{CH}_{4}$ excess using the ECLIPSE inven-

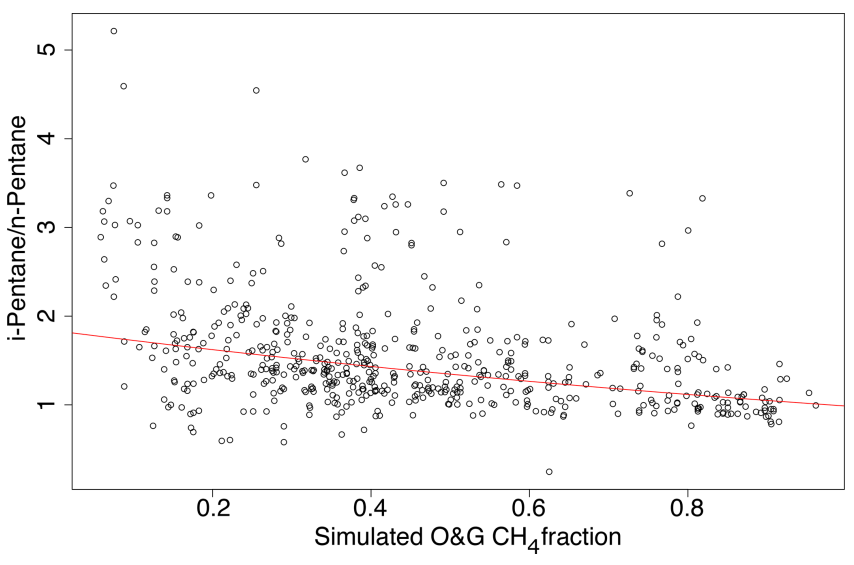

Figure 11. Scatterplot of the fraction of simulated methane due to OG sources against the $i$-pentane to $n$-pentane ratio. An exponential model is fitted to the data (red line).

tory for $\mathrm{CH}_{4}$ (light blue line in Fig. 8). The two inventories agree to a large extent for all regions apart from the Arabian Gulf, where ECLIPSE yields a mean excess that is $65 \%$ higher than the EDGAR simulation (mean 255 and $156 \mathrm{ppb}$, respectively). For the Arabian Gulf, none of the inventories yield significant correlation, suggesting a poor representation of spatial distribution of emissions. ECLIPSE also simulates much higher $\mathrm{CH}_{4}$ excess in the vicinity of the Fateh 
oil field, with a local maximum of $566 \mathrm{ppb}$ compared to the EDGAR simulation that yields $150 \mathrm{ppb}$. In the northern part of the Arabian Gulf, ECLIPSE also simulates higher excess concentrations than EDGAR, but the ECLIPSE simulation shows a much better agreement with the observed $\mathrm{CH}_{4}$ variability, especially at the Kuwait coast on 30 and 31 July. The enhanced divergence among simulations using different inventories is most likely due to the increasing differences between inventories at finer spatial scales, as has been highlighted by Ciais et al. (2010) for $\mathrm{CO}_{2}$ in Europe. Furthermore, the high skewness in the regional distribution of emission for each facility may not be properly represented in the inventories (Zavala-Araiza et al., 2015), leading to strong discrepancies between simulation and measurements when measuring directly near such facilities. Overall, in the southern part of the Arabian Gulf, where gas fields represent a larger part of the OG extraction, EDGAR tends to accurately represent specific plumes (see point B in Fig. 10), which is not the case for ECLIPSE. However, on average both EDGAR and ECLIPSE tend to overestimate the signal (Fig. 8). In the northern part of the Arabian Gulf, where oil extraction is comparatively more represented, the EDGAR inventory tends to underestimate the measurements, while ECLIPSE underestimates the measurements for Leg 1 and overestimates it for Leg 2.

Accurately simulating plumes measured in the vicinity of point sources is highly dependent on the injection position of emissions in the inventory. Here we used inventory maps in the model with a resolution of $0.1^{\circ} \times 0.1^{\circ}$ for EDGAR; hence, a point source is spread within $10 \mathrm{~km}$. This may result in discrepancies between observations and simulated fields. This is particularly true if an important source point is within the distance corresponding to the spatial resolution of the wind fields driving the model (here, $1^{\circ} \times 1^{\circ}$, i.e., approximately $100 \mathrm{~km}$ ). Capturing local sea breeze patterns might be challenging for the model's driving wind field. This may cause the strong overestimations of $\mathrm{CH}_{4}$ enhancements over the southeastern part of the Arabian Gulf.

Unaccounted for time variations may also play a role in model-observation mismatch. Since the inventory is static, any daily or weekly pattern in emissions would not be reproduced in the model, which could be important when the ship is in harbor. Moreover, venting, incomplete flaring combustion and maintenance activities are typically leading to intermittent $\mathrm{CH}_{4}$ emission. In a study of black carbon emissions from flaring in Siberia, Petäjä et al. (2020, their Sect. 3.8.2) found that accounting for actual times of flaring instead of using annual means can significantly improve the simulation of downwind atmospheric measurements.

Since our study is focusing on anthropogenic emissions and given the low natural emissions in the eastern Mediterranean and Middle East area (Saunois et al., 2020), we used only anthropogenic inventories in our study. However, some level of sensitivity to natural fluxes can be expected. The $\mathrm{CO}_{2}$ sink would affect concentrations downwind of large forested areas, for example around the eastern Mediterranean basin. However, biogenic sinks are not likely to play a role in the desert-dominated regions of the Arabian Peninsula.

OG extraction at the country level varies from year to year, and the life cycle of individual productive fields evolves over several years. As a result, changes over time of the emission spatial pattern and intensity as reported in inventories for specific years may affect the accuracy of the simulation. Here, our simulation uses the EDGAR inventory for 2012. Oil production in the Middle East increased by $10.8 \%$ between 2012 and 2017 , while gas production increased by $19.2 \%$ (Dudley, 2019). According to the most recent available update of the inventory (EDGAR v5.0), OG emissions have increased by $8.61 \%$ for countries bordering the Arabian Gulf between 2012 and 2015, the latest available year. In order to investigate the potential evolution of the oil extraction activity, the evolution of flaring activity between 2012 and 2017 has been investigated. Flaring data are obtained from the VIIRS Skytruth nightlight product (Elvidge et al., 2016) for the Middle East. Flaring has shown a 2-fold increase in intensity (in terms of number of hotspots detected from space) over the period, which suggests that the $8.61 \%$ increase in inventory OG emissions from the neighboring countries is not sufficient to match the increase in extraction activity. The spatial distribution of the flaring has not varied significantly over the period. In addition to flaws in the inventory for its base year, accounting for increased activity over the period 20122017 would lead to further overestimations between model and observations linked to OG activity in the Arabian Gulf. This therefore does not contribute to explaining the model overestimation, especially in the southern part of the Arabian Gulf.

\section{Conclusion}

The AQABA campaign provided the first overview of the regional distribution of $\mathrm{CH}_{4}$ and $\mathrm{CO}_{2}$. Three distinct elements are identified in the distribution of GHG during the campaign. The Mediterranean Sea is dominated by European emissions. The Gulf of Aden and the Arabian Sea are in an air mass relatively poor in GHG, with air masses originating from eastern Africa. The Red Sea, the Gulf of Oman and Arabian Gulf showed high $\mathrm{CO}_{2}$ and $\mathrm{CH}_{4}$ concentrations.

The $\mathrm{C}_{2} \mathrm{H}_{6}: \mathrm{CH}_{4}$ and $i$-pentane to $n$-pentane ratios suggest that over the Red Sea, Gulf of Oman and Arabian Gulf, $\mathrm{CH}_{4}$ enhancements are originating from $\mathrm{OG}$ emissions, especially in the latter area. Repeated $\mathrm{CH}_{4}$ enhancements over the Suez Canal, Red Sea and Arabian Gulf are also unambiguously identified as emitted from local OG extraction and exploitation. This is clearly supported by a Lagrangian simulation based on the EDGAR inventory, showing that $81 \%$ of excess $\mathrm{CH}_{4}$ over the Arabian Gulf is due to the exploitation of OG. The $\mathrm{CO}_{2}$ variability is dominated in this area by anthropogenic emissions, with a dominant contribution from the 
power industry and the oil-refining and transformation sectors.

While the model predicts a dominant contribution from OG exploitation to $\mathrm{CH}_{4}$ enhancements, in agreement with the light alkanes measurements, only weak quantitative agreement has been found between modeled and measured $\mathrm{CH}_{4}$. This is most likely explained by a combination of factors, including error in the inventory, poor dilution in the model in the vicinity of the sources, poor distribution of the point source intensities and a lack of representation of temporal variations in emission patterns. A similar simulation using a different inventory (ECLIPSE) tended to overestimate the measured $\mathrm{CH}_{4}$ close to sources in the southern Arabian Gulf. Despite these compounded uncertainties, our study provides strong indication that inventories overestimate part of the regional upstream OG emissions in Middle Eastern countries neighboring the Arabian Gulf, especially linked to gas extraction. In contrast, in the northern Arabian Gulf there are comparatively more oil fields, and in that region the measured methane is generally underestimated by the simulations. Increases in OG emissions in the Middle East compared to the reference year of the inventories would further enhance overestimations but could partly explain the underestimation for the northern Arabian Gulf area. Our study also shows that the inventories must be improved for the spatial distribution of emissions in this area, where emissions are dominated by the sector of OG extraction, transport and transformation. Separating onshore from offshore emissions would require a dedicated modeling study investigating local atmospheric circulation combined with atmospheric composition measurements.
More targeted measurements specifically investigating offshore and onshore extraction sites will enable a better understanding of the distribution of emission in the area. Assessing emissions from individual wells and processing facilities with dedicated measurements and combining these estimates at the regional level would be necessary to further improve our knowledge of actual OG emissions in the Middle East. Combining $\mathrm{CH}_{4}$ and alkane measurements offers the potential to (1) separate the $\mathrm{OG}$ component of measured $\mathrm{CH}_{4}$ from other sources and (2) to investigate the fraction of emissions linked to each phase of OG value chain at the regional and local level, from extraction to end usage through storage, transport and processing. 


\section{Appendix A}

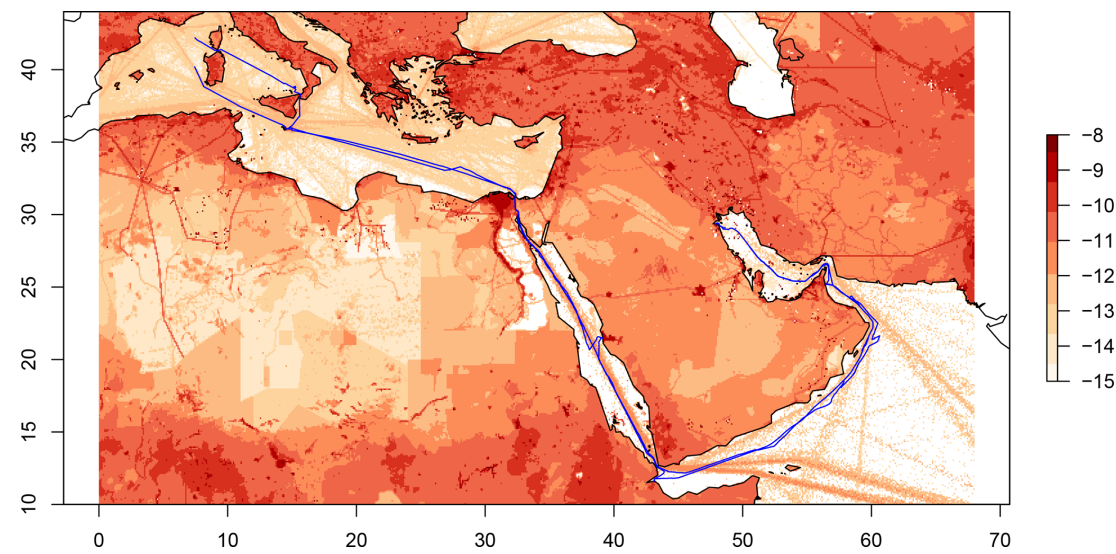

Figure A1. $\mathrm{CH}_{4}$ emissions predicted by EDGAR v4.3.2 for year 2012 in the Mediterranean and Middle East, expressed in $\log \left(\mathrm{kg} \mathrm{CH}_{4} \mathrm{~m}^{-2} \mathrm{~s}^{-1}\right)$. The ship trajectory is shown in blue.

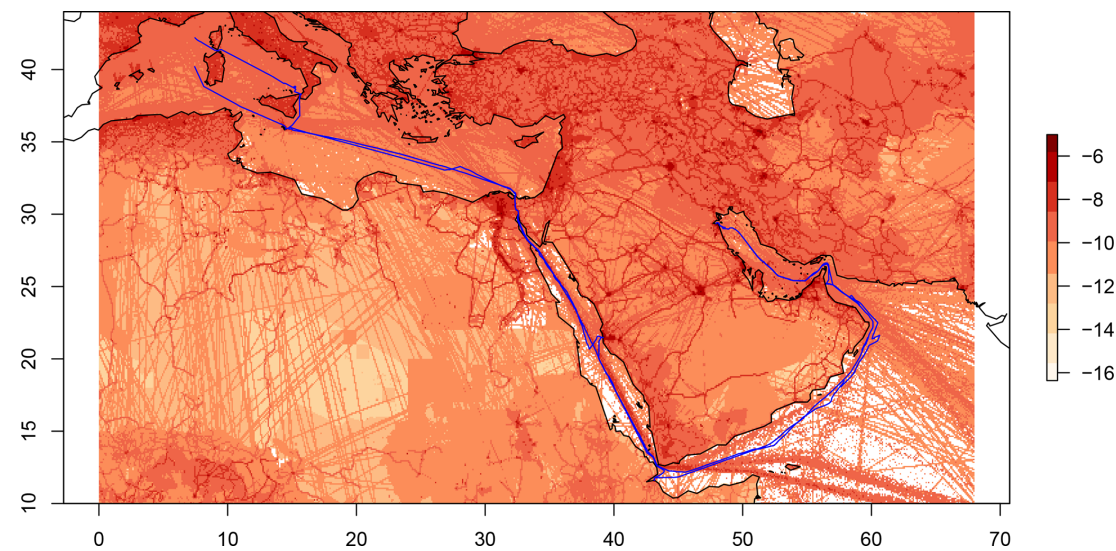

Figure A2. $\mathrm{CO}_{2}$ emissions predicted by EDGAR v4.3.2 for year 2012 in the Mediterranean and Middle East, expressed in $\log 10\left(\mathrm{~kg} \mathrm{CO}_{2} \mathrm{~m}^{-2} \mathrm{~s}^{-1}\right)$. The ship trajectory is shown in blue.
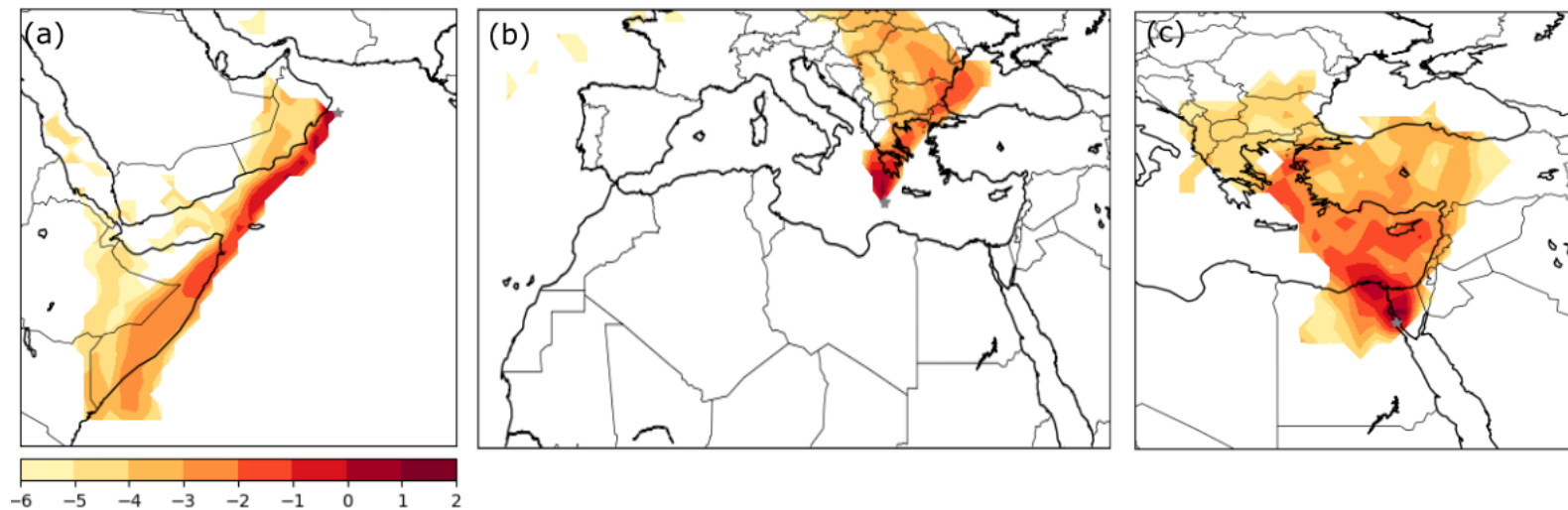

Figure A3. Footprints for ship positions on (a) 8 August 2017 at 06:00 UTC, (b) 27 August 2017 at 08:00 UTC and (c) 4 July 2017 at 07:00 UTC. See the main text for details. Footprints are expressed as $\log 10$ of residence time (s) of particles below $2000 \mathrm{~m}$. The ship's position is indicated by the gray star. 
Data availability. The data used in this work are available upon reasonable request directly from the authors.

Author contributions. JDP conceived this study and wrote the manuscript. AR, AB and JDP performed and analyzed the FLEXPART simulations. EB, JW and LE did the alkane measurements. JDP and MD did the greenhouse gas measurements. IT provided complementary data. HH was the chief of mission. JL was the PI of the campaign. All authors contributed to the manuscript.

Competing interests. The authors declare that they have no conflict of interest.

Disclaimer. Publisher's note: Copernicus Publications remains neutral with regard to jurisdictional claims in published maps and institutional affiliations.

Acknowledgements. The Max Planck Institute for Chemistry, Mainz, organized the AQABA campaign and chartered the ship. Thanks to Marcel Dorf, Dieter Scharffe, Charlotte Beall, Claus Koeppel, and the many other participants of the cruise for their crucial contributions. Jean Sciare enabled the presence of our measurements during the campaign. Olivier Laurent, Céline Lett and Laurence Vialettes (ICOS teams at LSCE) were key contributors in designing and implementing the measurement setup. Thanks to Hays Ships and the R/V Kommandor Iona crew for their successful and friendly implementation of the cruise.

Financial support. This research has been supported by the EMME-CARE project from the European Union's Horizon 2020 Research and Innovation Programme (grant agreement no. 856612), and the Government of the Republic of Cyprus.

Review statement. This paper was edited by Eduardo Landulfo and reviewed by Carlos Oliveira and two anonymous referees.

\section{References}

Alvarez, R. A., Zavala-Araiza, D., Lyon, D. R., Allen, D. T., Barkley, Z. R., Brandt, A. R., Davis, K. J., Herndon, S. C., Jacob, D. J., Karion, A., Kort, E. A., Lamb, B. K., Lauvaux, T., Maasakkers, J. D., Marchese, A. J., Omara, M., Pacala, S. W., Peischl, J., Robinson, A. L., Shepson, P. B., Sweeney, C., Townsend-Small, A., Wofsy, S. C., and Hamburg, S. P.: Assessment of methane emissions from the U.S. oil and gas supply chain, Science, 361, 186-188, https://doi.org/10.1126/science.aar7204, 2018.

Assan, S., Baudic, A., Guemri, A., Ciais, P., Gros, V., and Vogel, F. R.: Characterization of interferences to in situ observations of $\delta^{13} \mathrm{CH}_{4}$ and $\mathrm{C}_{2} \mathrm{H}_{6}$ when using a cavity ring-down spec- trometer at industrial sites, Atmos. Meas. Tech., 10, 2077-2091, https://doi.org/10.5194/amt-10-2077-2017, 2017.

Berchet, A., Pison, I., Crill, P. M., Thornton, B., Bousquet, P., Thonat, T., Hocking, T., Thanwerdas, J., Paris, J.-D., and Saunois, M.: Using ship-borne observations of methane isotopic ratio in the Arctic Ocean to understand methane sources in the Arctic, Atmos. Chem. Phys., 20, 3987-3998, https://doi.org/10.5194/acp-20-3987-2020, 2020.

Bourtsoukidis, E., Ernle, L., Crowley, J. N., Lelieveld, J., Paris, J.-D., Pozzer, A., Walter, D., and Williams, J.: Nonmethane hydrocarbon $\left(\mathrm{C}_{2}-\mathrm{C}_{8}\right)$ sources and sinks around the Arabian Peninsula, Atmos. Chem. Phys., 19, 7209-7232, https://doi.org/10.5194/acp-19-7209-2019, 2019.

Bourtsoukidis, E., Pozzer, A., Sattler, T., Matthaios, V. N., Ernle, L., Edtbauer, A., Fischer, H., Könemann, T., Osipov, S., Paris, J.-D., Pfannerstill, E. Y., Stönner, C., Tadic, I., Walter, D., Wang, N., Lelieveld, J., and Williams, J.: The Red Sea Deep Water is a potent source of atmospheric ethane and propane, Nat. Commun., 11, 447, https://doi.org/10.1038/s41467-020-14375-0, 2020.

Celik, S., Drewnick, F., Fachinger, F., Brooks, J., Darbyshire, E., Coe, H., Paris, J.-D., Eger, P. G., Schuladen, J., Tadic, I., Friedrich, N., Dienhart, D., Hottmann, B., Fischer, H., Crowley, J. N., Harder, H., and Borrmann, S.: Influence of vessel characteristics and atmospheric processes on the gas and particle phase of ship emission plumes: in situ measurements in the Mediterranean Sea and around the Arabian Peninsula, Atmos. Chem. Phys., 20, 4713-4734, https://doi.org/10.5194/acp20-4713-2020, 2020.

Ciais, P., Paris, J. D., Marland, G., Peylin, P., Piao, S. L., Levin, I., Pregger, T., Scholz, Y., Friedrich, R., Rivier, L., Houwelling, S., Schulze, E. D., and members of the CARBOEUROPE synthesis team: The European carbon balance, Part 1: fossil fuel emissions, Global Change Biol., 16, 1395-1408, 2010.

Conti, J., Holtberg, P., Diefenderfer, J., LaRose, A., Turnure, J. T., and Westfall, L.: International Energy Outlook 2016 With Projections to 2040, USDOE Energy Information Administration, United States: N. p., https://doi.org/10.2172/1296780, 2016.

Defratyka, S. M., Paris, J.-D., Yver-Kwok, C., Loeb, D., France, J., Helmore, J., Yarrow, N., Gros, V., and Bousquet, P.: Ethane measurement by Picarro CRDS G2201-i in laboratory and field conditions: potential and limitations, Atmos. Meas. Tech., 14, 50495069, https://doi.org/10.5194/amt-14-5049-2021, 2021.

Dlugokencky, E. and Tans, P.: Trends in atmospheric carbon dioxide, National Oceanic \& Atmospheric Administration, Earth System Research Laboratory (NOAA/ESRL), available at: http: //www.esrl.noaa.gov/gmd/ccgg/trends/global.html, last access: 26 July 2018.

Dudley, B.: Statistical Review of World Energy 68th Edition, Technical Report, BP p.l.c., London, UK, 2019.

Elvidge, C. D., Zhizhin, M., Baugh, K., Hsu, F.-C., and Ghosh, T.: Methods for Global Survey of Natural Gas Flaring from Visible Infrared Imaging Radiometer Suite Data, Energies 9, 14, https://doi.org/10.3390/en9010014, 2016.

Friedlingstein, P., Jones, M. W., O’Sullivan, M., Andrew, R. M., Hauck, J., Peters, G. P., Peters, W., Pongratz, J., Sitch, S., Le Quéré, C., Bakker, D. C. E., Canadell, J. G., Ciais, P., Jackson, R. B., Anthoni, P., Barbero, L., Bastos, A., Bastrikov, V., Becker, M., Bopp, L., Buitenhuis, E., Chandra, N., Chevallier, F., Chini, L. P., Currie, K. I., Feely, R. A., Gehlen, M., Gilfillan, 
D., Gkritzalis, T., Goll, D. S., Gruber, N., Gutekunst, S., Harris, I., Haverd, V., Houghton, R. A., Hurtt, G., Ilyina, T., Jain, A. K., Joetzjer, E., Kaplan, J. O., Kato, E., Klein Goldewijk, K., Korsbakken, J. I., Landschützer, P., Lauvset, S. K., Lefèvre, N., Lenton, A., Lienert, S., Lombardozzi, D., Marland, G., McGuire, P. C., Melton, J. R., Metzl, N., Munro, D. R., Nabel, J. E. M. S., Nakaoka, S.-I., Neill, C., Omar, A. M., Ono, T., Peregon, A., Pierrot, D., Poulter, B., Rehder, G., Resplandy, L., Robertson, E., Rödenbeck, C., Séférian, R., Schwinger, J., Smith, N., Tans, P. P., Tian, H., Tilbrook, B., Tubiello, F. N., van der Werf, G. R., Wiltshire, A. J., and Zaehle, S.: Global Carbon Budget 2019, Earth Syst. Sci. Data, 11, 1783-1838, https://doi.org/10.5194/essd-111783-2019, 2019.

Friedlingstein, P., O’Sullivan, M., Jones, M. W., Andrew, R. M., Hauck, J., Olsen, A., Peters, G. P., Peters, W., Pongratz, J., Sitch, S., Le Quéré, C., Canadell, J. G., Ciais, P., Jackson, R. B., Alin, S., Aragão, L. E. O. C., Arneth, A., Arora, V., Bates, N. R., Becker, M., Benoit-Cattin, A., Bittig, H. C., Bopp, L., Bultan, S., Chandra, N., Chevallier, F., Chini, L. P., Evans, W., Florentie, L., Forster, P. M., Gasser, T., Gehlen, M., Gilfillan, D., Gkritzalis, T., Gregor, L., Gruber, N., Harris, I., Hartung, K., Haverd, V., Houghton, R. A., Ilyina, T., Jain, A. K., Joetzjer, E., Kadono, K., Kato, E., Kitidis, V., Korsbakken, J. I., Landschützer, P., Lefèvre, N., Lenton, A., Lienert, S., Liu, Z., Lombardozzi, D., Marland, G., Metzl, N., Munro, D. R., Nabel, J. E. M. S., Nakaoka, S.-I., Niwa, Y., O’Brien, K., Ono, T., Palmer, P. I., Pierrot, D., Poulter, B., Resplandy, L., Robertson, E., Rödenbeck, C., Schwinger, J., Séférian, R., Skjelvan, I., Smith, A. J. P., Sutton, A. J., Tanhua, T., Tans, P. P., Tian, H., Tilbrook, B., van der Werf, G., Vuichard, N., Walker, A. P., Wanninkhof, R., Watson, A. J., Willis, D., Wiltshire, A. J., Yuan, W., Yue, X., and Zaehle, S.: Global Carbon Budget 2020, Earth Syst. Sci. Data, 12, 3269 3340, https://doi.org/10.5194/essd-12-3269-2020, 2020.

GIE-MARCOGAZ: Potential ways the gas industry can contribute to the reduction of methane emissions, Report for the Madrid Forum, 5-6 June 2019, available at: https://www.gie.eu/ publications/methane-emission/methane-emissions-report/ (last access: 14 August 2021), 2019.

Gilman, J. B., Lerner, B. M., Kuster, W. C., and de Gouw, J. A.: Source Signature of Volatile Organic Compounds from Oil and Natural Gas Operations in Northeastern Colorado, Environ. Sci. Technol., 47, 1297-1305, https://doi.org/10.1021/es304119a, 2013.

Hazan, L., Tarniewicz, J., Ramonet, M., Laurent, O., and Abbaris, A.: Automatic processing of atmospheric $\mathrm{CO}_{2}$ and $\mathrm{CH}_{4}$ mole fractions at the ICOS Atmosphere Thematic Centre, Atmos. Meas. Tech., 9, 4719-4736, https://doi.org/10.5194/amt-9-47192016, 2016.

Helfter, C., Mullinger, N., Vieno, M., O’Doherty, S., Ramonet, M., Palmer, P. I., and Nemitz, E.: Country-scale greenhouse gas budgets using shipborne measurements: a case study for the UK and Ireland, Atmos. Chem. Phys., 19, 3043-3063, https://doi.org/10.5194/acp-19-3043-2019, 2019.

Hmiel, B., Petrenko, V. V., Dyonisius, M. N., Buizert, C., Smith, A. M., Place, P. F., Harth, C., Beaudette, R., Hua, Q., Yang, B., Vimont, I., Michel, S. E., Severinghaus, J. P., Etheridge, D., Bromley, T., Schmitt, J., Faïn, X., Weiss, R. F., and Dlugokencky, E.: Preindustrial $14 \mathrm{CH}_{4}$ indicates greater anthropogenic fossil $\mathrm{CH}_{4}$ emissions, Nature, 578, 409-412, https://doi.org/10.1038/s41586-020-1991-8, 2020.

Höglund-Isaksson, L.: Global anthropogenic methane emissions 2005-2030: technical mitigation potentials and costs, Atmos. Chem. Phys., 12, 9079-9096, https://doi.org/10.5194/acp-129079-2012, 2012.

Huang, G., Brook, R., Crippa, M., Janssens-Maenhout, G., Schieberle, C., Dore, C., Guizzardi, D., Muntean, M., Schaaf, E., and Friedrich, R.: Speciation of anthropogenic emissions of non-methane volatile organic compounds: a global gridded data set for 1970-2012, Atmos. Chem. Phys., 17, 7683-7701, https://doi.org/10.5194/acp-17-7683-2017, 2017.

IEA: Methane Tracker 2020, IEA, Paris, France, available at: https: //www.iea.org/reports/methane-tracker-2020 (last access: $14 \mathrm{Au}-$ gust 2021), 2020.

Jackson, R. B., Friedlingstein, P., Andrew, R. M., Canadell, J. G., Le Quéré, C., and Peters, G. P.: Persistent fossil fuel growth threatens the Paris Agreement and planetary health, Environ. Res. Lett., 14, 121001, https://doi.org/10.1088/17489326/ab57b3, 2019.

Jackson, R. B., Saunois, M., Bousquet, P., Canadell, J. G., Poulter, B., Stavert, A. R., Bergamaschi, P., Niwa, Y., Segers, A., and Tsuruta, A.: Increasing anthropogenic methane emissions arise equally from agricultural and fossil fuel sources, Environ. Res. Lett., 15, 071002, https://doi.org/10.1088/17489326/ab9ed2, 2020.

Janssens-Maenhout, G., Crippa, M., Guizzardi, D., Muntean, M., Schaaf, E., Olivier, J. G. J., Peters, J. A. H. W., and Schure, K. M.: Fossil $\mathrm{CO}_{2}$ and GHG emissions of all world countries, EUR 28766 EN, Publications Office of the European Union, Luxembourg, ISBN 978-92-79-73207-2, https://doi.org/10.2760/709792, 2017.

Janssens-Maenhout, G., Crippa, M., Guizzardi, D., Muntean, M., Schaaf, E., Dentener, F., Bergamaschi, P., Pagliari, V., Olivier, J. G. J., Peters, J. A. H. W., van Aardenne, J. A., Monni, S., Doering, U., Petrescu, A. M. R., Solazzo, E., and Oreggioni, G. D.: EDGAR v4.3.2 Global Atlas of the three major greenhouse gas emissions for the period 1970-2012, Earth Syst. Sci. Data, 11, 959-1002, https://doi.org/10.5194/essd-11-959-2019, 2019.

Jones, A., Haywood, J. M., and Jones, C. D.: Can reducing black carbon and methane below RCP2.6 levels keep global warming below $1.5^{\circ} \mathrm{C}$ ?, Atmos. Sci. Lett., 19, e821, https://doi.org/10.1002/asl.821, 2018.

Lelieveld, J., Berresheim, H., Borrmann, S., Crutzen, P. J., Dentener, F. J., Fischer, H., Feichter, J., Flatau, P. J., Heland, J., Holzinger, R., Korrmann, R., Lawrence, M. G., Levin, Z., Markowicz, K. M., Mihalopoulos, N., Minikin, A., Ramanathan, V., de Reus, M., Roelofs, G. J., Scheeren, H. A., Sciare, J., Schlager, H., Schultz, M., Siegmund, P., Steil, B., Stephanou, E. G., Stier, P., Traub, M., Warneke, C., Williams, J., and Ziereis, H.: Global air pollution crossroads over the Mediterranean, Science, 298, 794-799, https://doi.org/10.1126/science.1075457, 2002.

Lelieveld, J., Hadjinocolaou, P., Kostopoulou, E., Chenoweth, J., El Maayar, M., Giannakopoulos, C., Hannides, C., Langa, M. A., Tanarhte, M., Tyrlis, E., and Xoplaki, E.: Climate change and impacts in the eastern Mediterranean and Middle East, Clim. Change, 114, 667-687, 2012. 
Le Quéré, C., Andrew, R. M., Friedlingstein, P., Sitch, S., Hauck, J., Pongratz, J., Pickers, P. A., Korsbakken, J. I., Peters, G. P., Canadell, J. G., Arneth, A., Arora, V. K., Barbero, L., Bastos, A., Bopp, L., Chevallier, F., Chini, L. P., Ciais, P., Doney, S. C., Gkritzalis, T., Goll, D. S., Harris, I., Haverd, V., Hoffman, F. M., Hoppema, M., Houghton, R. A., Hurtt, G., Ilyina, T., Jain, A. K., Johannessen, T., Jones, C. D., Kato, E., Keeling, R. F., Goldewijk, K. K., Landschützer, P., Lefèvre, N., Lienert, S., Liu, Z., Lombardozzi, D., Metzl, N., Munro, D. R., Nabel, J. E. M. S., Nakaoka, S., Neill, C., Olsen, A., Ono, T., Patra, P., Peregon, A., Peters, W., Peylin, P., Pfeil, B., Pierrot, D., Poulter, B., Rehder, G., Resplandy, L., Robertson, E., Rocher, M., Rödenbeck, C., Schuster, U., Schwinger, J., Séférian, R., Skjelvan, I., Steinhoff, T., Sutton, A., Tans, P. P., Tian, H., Tilbrook, B., Tubiello, F. N., van der Laan-Luijkx, I. T., van der Werf, G. R., Viovy, N., Walker, A. P., Wiltshire, A. J., Wright, R., Zaehle, S., and Zheng, B.: Global Carbon Budget 2018, Earth Syst. Sci. Data, 10, 21412194, https://doi.org/10.5194/essd-10-2141-2018, 2018.

Lowry, D., Fisher, R. E., France, J. L., Coleman, M., Lanoisellé, M., Zazzeri, G., Nisbet, E. G., Shaw, J. T., Allen, G., Pitt, J., and Ward, R. S.: Environmental baseline monitoring for shale gas development in the UK: Identification and geochemical characterization of local source emissions of methane to atmosphere, Sci. Total Environ., 708, 134600, https://doi.org/10.1016/j.scitotenv.2019.134600, 2020.

Lyon, D. R., Alvarez, R. A., Zavala-Araiza, D., Brandt, A. R., Jackson, R. B., and Hamburg, S. P.: Aerial Surveys of Elevated Hydrocarbon Emissions from Oil and Gas Production Sites, Environ. Sci. Technol., 50, 4877-4886, https://doi.org/10.1021/acs.est.6b00705, 2016.

McNorton, J., Wilson, C., Gloor, M., Parker, R. J., Boesch, H., Feng, W., Hossaini, R., and Chipperfield, M. P.: Attribution of recent increases in atmospheric methane through 3D inverse modelling, Atmos. Chem. Phys., 18, 18149-18168, https://doi.org/10.5194/acp-18-18149-2018, 2018.

Nisbet, E. G., Fisher, R. E., Lowry, D., France, J. L., Allen, G., Bakkaloglu, S., Broderick, T. J., Cain, M., Coleman, M., Fernandez, J., Forster, G., Griffiths, P. T., Iverach, C. P., Kelly, B. F. J., Manning, M. R., Nisbet-Jones, P. B. R., Pyle, J. A., TownsendSmall, A., al-Shalaan, A., Warwick, N., and Zazzeri, G.: Methane mitigation: methods to reduce emissions, on the path to the Paris agreement, Rev. Geophys., 58, e2019RG000675, https://doi.org/10.1029/2019RG000675, 2020

Ocko, I. B., Sun, T., Shindell, D., Oppenheimer, M., Hristov, A. N., Pacala, S. W., Mauzerall, D. L., Xu, Y., and Hamburg, S. P.: Acting Rapidly to Deploy Readily Available Methane Mitigation Measures by Sector Can Immediately Slow Global Warming, Environ. Res. Lett., 16, 054042, https://doi.org/10.1088/17489326/abf9c8, 2021.

OPEC: Annual statistical bulletin, 2020, available at: https://asb. opec.org/index.html, last access: 9 December 2020.

Parrish, D. D., Stohl, A., Forster, C., Atlas, E. L., Blake, D. R., Goldan, P. D., Kuster, W. C., and de Gouw, J. A.: Effects of mixing on evolution of hydrocarbon ratios in the troposphere, J. Geophys. Res., 112, D10S34, https://doi.org/10.1029/2006JD007584, 2007.

Petäjä, T., Duplissy, E.-M., Tabakova, K., Schmale, J., Altstädter, B., Ancellet, G., Arshinov, M., Balin, Y., Baltensperger, U., Bange, J., Beamish, A., Belan, B., Berchet, A., Bossi, R., Cairns,
W. R. L., Ebinghaus, R., El Haddad, I., Ferreira-Araujo, B., Franck, A., Huang, L., Hyvärinen, A., Humbert, A., Kalogridis, A.-C., Konstantinov, P., Lampert, A., MacLeod, M., Magand, O., Mahura, A., Marelle, L., Masloboev, V., Moisseev, D., Moschos, V., Neckel, N., Onishi, T., Osterwalder, S., Ovaska, A., Paasonen, P., Panchenko, M., Pankratov, F., Pernov, J. B., Platis, A., Popovicheva, O., Raut, J.-C., Riandet, A., Sachs, T., Salvatori, R., Salzano, R., Schröder, L., Schön, M., Shevchenko, V., Skov, H., Sonke, J. E., Spolaor, A., Stathopoulos, V. K., Strahlendorff, M., Thomas, J. L., Vitale, V., Vratolis, S., Barbante, C., Chabrillat, S., Dommergue, A., Eleftheriadis, K., Heilimo, J., Law, K. S., Massling, A., Noe, S. M., Paris, J.-D., Prévôt, A. S. H., Riipinen, I., Wehner, B., Xie, Z., and Lappalainen, H. K.: Overview: Integrative and Comprehensive Understanding on Polar Environments (iCUPE) - concept and initial results, Atmos. Chem. Phys., 20, 8551-8592, https://doi.org/10.5194/acp20-8551-2020, 2020.

Peters, G. P., Davis, S. J., and Andrew, R.: A synthesis of carbon in international trade, Biogeosciences, 9, 3247-3276, https://doi.org/10.5194/bg-9-3247-2012, 2012.

Pfannerstill, E. Y., Wang, N., Edtbauer, A., Bourtsoukidis, E., Crowley, J. N., Dienhart, D., Eger, P. G., Ernle, L., Fischer, H., Hottmann, B., Paris, J.-D., Stönner, C., Tadic, I., Walter, D., Lelieveld, J., and Williams, J.: Shipborne measurements of total $\mathrm{OH}$ reactivity around the Arabian Peninsula and its role in ozone chemistry, Atmos. Chem. Phys., 19, 11501-11523, https://doi.org/10.5194/acp-19-11501-2019, 2019.

Pisso, I., Sollum, E., Grythe, H., Kristiansen, N. I., Cassiani, M., Eckhardt, S., Arnold, D., Morton, D., Thompson, R. L., Groot Zwaaftink, C. D., Evangeliou, N., Sodemann, H., Haimberger, L., Henne, S., Brunner, D., Burkhart, J. F., Fouilloux, A., Brioude, J., Philipp, A., Seibert, P., and Stohl, A.: The Lagrangian particle dispersion model FLEXPART version 10.4, Geosci. Model Dev., 12, 4955-4997, https://doi.org/10.5194/gmd-12-4955-2019, 2019.

Purvis, R. M., Lewis, A. C., Carney, R. A., McQuaid, J. B., Arnold, S. R., Methven, J., Barjat, H., Dewey, K., Kent, J., Monks, P. S., Carpenter, L. J., Brough, N., Penkett, S. A., and Reeves, C. E.: Rapid uplift of nonmethane hydrocarbons in a cold front over central Europe, J. Geophys. Res.-Atmos., 108, 4224, https://doi.org/10.1029/2002JD002521, 2003.

Ramonet, M., Ciais, P., Aalto, T., Aulagnier, C., Chevallier, F., Cipriano, D., Conway, T., Haszpra, L., Kazan, V., Meinhardt, F., Paris, J.-D., Schmid, M., Simmonds, P., Xueref-Rémy, I., and Necki, J.: A recent build-up of atmospheric $\mathrm{CO}_{2}$ over Europe. Part 1: observed signals and possible explanations, Tellus B, 62, 1-13, https://doi.org/10.1111/j.1600-0889.2009.00442.x, 2010.

Reddy, C. M., Arey, J. S., Seewald, J. S., Sylva, S. P., Lemkau, K. L., Nelson, R. K., Carmichael, C. A., McIntyre, C. P., Fenwick, J., Ventura, G. T., van Mooy, B. A. S., and Camilli, R. Composition and fate of gas and oil released to the water column during the Deepwater Horizon oil spill, P. Natl. Acad. Sci. USA, 109, 20,229-20,234, https://doi.org/10.1073/pnas.1101242108, 2012.

Rella, C. W., Hoffnagle, J., He, Y., and Tajima, S.: Local- and regional-scale measurements of $\mathrm{CH}_{4}, \delta^{13} \mathrm{CH}_{4}$, and $\mathrm{C}_{2} \mathrm{H}_{6}$ in the Uintah Basin using a mobile stable isotope analyzer, Atmos. Meas. Tech., 8, 4539-4559, https://doi.org/10.5194/amt-8-45392015, 2015. 
Ricaud, P., Zbinden, R., Catoire, V., Brocchi, V., Dulac, F., Hamonou, E., Canonici, J., El Amraoui, L., Massart, S., Piguet, B., Dayan, U., Nabat, P., Sciare, J., Ramonet, M., Delmotte, M., di Sarra, A., Sferlazzo, D., Di Iorio, T., Piacentino, S., Cristofanelli, P., Mihalopoulos, N., Kouvarakis, G., Pikridas, M., Savvides, C., Mamouri, R.-E., Nisantzi, A., Hadjimitsis, D., Attié, J.-L., Ferré, H., Kangah, Y., Jaidan, N., Guth, J., Jacquet, P., Jaidan, J., Guth, P., Robert, C., Bourdon, A., Bourdinot, J.-F., Etienne, J.-C., Krysztofiak, G., Theron, P., and Chevrier, S.: The GLAM airborne campaign across the Mediterranean Basin, Bull. Am. Met. Soc., 99.2, 361-380, https://doi.org/10.1175/BAMS-D-160226.1, 2018.

Rogelj, J., Shindell, D., Jiang, K., Fifita, S., Forster, P., Ginzburg, V., Handa, C., Kheshgi, H., Kobayashi, S., Kriegler, E., Mundaca, L., Seferian, R., and Vilarino, M. V.: Mitigation Pathways Compatible with $1.5^{\circ} \mathrm{C}$ in the Context of Sustainable Development, in: Global Warming of $1.5^{\circ} \mathrm{C}$. An IPCC Special Report on the impacts of global warming of $1.5^{\circ} \mathrm{C}$ above pre-industrial levels and related global greenhouse gas emission pathways, in the context of strengthening the global response to the threat of climate change, sustainable development, and efforts to eradicate poverty, edited by: Masson-Delmotte, V., Zhai, P., Pörtner, H.-O., Roberts, D., Skea, J., Shukla, P. R., Pirani, A., Moufouma-Okia, W., Péan, C., Pidcock, R., Connors, S., Matthews, J. B. R., Chen, Y., Zhou, X., Gomis, M. I., Lonnoy, E., Maycock, T., Tignor, M., and Waterfield, T., available at: https://www.ipcc.ch/report/sr15/mitigationpathways-compatible-with-1-5c-in-the-context-of-sustainable4-development/ (last access: 14 August 2021), 2018.

Saunois, M., Bousquet, P., Poulter, B., Peregon, A., Ciais, P., Canadell, J. G., Dlugokencky, E. J., Etiope, G., Bastviken, D., Houweling, S., Janssens-Maenhout, G., Tubiello, F. N., Castaldi, S., Jackson, R. B., Alexe, M., Arora, V. K., Beerling, D. J., Bergamaschi, P., Blake, D. R., Brailsford, G., Bruhwiler, L., Crevoisier, C., Crill, P., Covey, K., Frankenberg, C., Gedney, N., HöglundIsaksson, L., Ishizawa, M., Ito, A., Joos, F., Kim, H.-S., Kleinen, T., Krummel, P., Lamarque, J.-F., Langenfelds, R., Locatelli, R., Machida, T., Maksyutov, S., Melton, J. R., Morino, I., Naik, V., O'Doherty, S., Parmentier, F.-J. W., Patra, P. K., Peng, C., Peng, S., Peters, G. P., Pison, I., Prinn, R., Ramonet, M., Riley, W. J., Saito, M., Santini, M., Schroeder, R., Simpson, I. J., Spahni, R., Takizawa, A., Thornton, B. F., Tian, H., Tohjima, Y., Viovy, N., Voulgarakis, A., Weiss, R., Wilton, D. J., Wiltshire, A., Worthy, D., Wunch, D., Xu, X., Yoshida, Y., Zhang, B., Zhang, Z., and Zhu, Q.: Variability and quasi-decadal changes in the methane budget over the period 2000-2012, Atmos. Chem. Phys., 17, 11135-11161, https://doi.org/10.5194/acp-17-111352017, 2017.

Saunois, M., Stavert, A. R., Poulter, B., Bousquet, P., Canadell, J. G., Jackson, R. B., Raymond, P. A., Dlugokencky, E. J., Houweling, S., Patra, P. K., Ciais, P., Arora, V. K., Bastviken, D., Bergamaschi, P., Blake, D. R., Brailsford, G., Bruhwiler, L., Carlson, K. M., Carrol, M., Castaldi, S., Chandra, N., Crevoisier, C., Crill, P. M., Covey, K., Curry, C. L., Etiope, G., Frankenberg, C., Gedney, N., Hegglin, M. I., Höglund-Isaksson, L., Hugelius, G., Ishizawa, M., Ito, A., Janssens-Maenhout, G., Jensen, K. M., Joos, F., Kleinen, T., Krummel, P. B., Langenfelds, R. L., Laruelle, G. G., Liu, L., Machida, T., Maksyutov, S., McDonald, K. C., McNorton, J., Miller, P. A., Melton, J. R., Morino,
I., Müller, J., Murguia-Flores, F., Naik, V., Niwa, Y., Noce, S., O’Doherty, S., Parker, R. J., Peng, C., Peng, S., Peters, G. P., Prigent, C., Prinn, R., Ramonet, M., Regnier, P., Riley, W. J., Rosentreter, J. A., Segers, A., Simpson, I. J., Shi, H., Smith, S. J., Steele, L. P., Thornton, B. F., Tian, H., Tohjima, Y., Tubiello, F. N., Tsuruta, A., Viovy, N., Voulgarakis, A., Weber, T. S., van Weele, M., van der Werf, G. R., Weiss, R. F., Worthy, D., Wunch, D., Yin, Y., Yoshida, Y., Zhang, W., Zhang, Z., Zhao, Y., Zheng, B., Zhu, Q., Zhu, Q., and Zhuang, Q.: The Global Methane Budget 2000-2017, Earth Syst. Sci. Data, 12, 15611623, https://doi.org/10.5194/essd-12-1561-2020, 2020.

Schwietzke, S., Sherwood, O. A., Bruhwiler, L. M. P., Miller, J. B., Etiope, G., Dlugokencky, E. J., Michel, S. E., Arling, V. A., Vaughn, B. H., White, J. W. C., and Tans, P. P.: Upward revision of global fossil fuel methane emissions based on isotope database, Nature, 538, 88-91, https://doi.org/10.1038/nature19797, 2016.

Seibert, P. and Frank, A.: Source-receptor matrix calculation with a Lagrangian particle dispersion model in backward mode, Atmos. Chem. Phys., 4, 51-63, https://doi.org/10.5194/acp-4-512004, 2004.

Simpson, I. J., Sulbaek Andersen, M. P., Meinardi, S., Bruhwiler, L., Blake, N. J., Helmig, D., Rowland, F. S., and Blake, D. R.: Long-term decline of global atmospheric ethane concentrations and implications for methane, Nature, 488, 490-494, https://doi.org/10.1038/nature11342, 2012.

Stohl, A. and Thomson, D. J.: A density correction for Lagrangian particle dispersion models, Bound.-Lay. Meteorol., 90, 155-167, 1999.

Tadic, I., Crowley, J. N., Dienhart, D., Eger, P., Harder, H., Hottmann, B., Martinez, M., Parchatka, U., Paris, J.-D., Pozzer, A., Rohloff, R., Schuladen, J., Shenolikar, J., Tauer, S., Lelieveld, J., and Fischer, H.: Net ozone production and its relationship to nitrogen oxides and volatile organic compounds in the marine boundary layer around the Arabian Peninsula, Atmos. Chem. Phys., 20, 6769-6787, https://doi.org/10.5194/acp-206769-2020, 2020.

Turner, A. J., Frankenberg, C., and Kort, E. A.: Interpreting contemporary trends in atmospheric methane, P. Natl. Acad. Sci. USA, 116, 2805-2813, https://doi.org/10.1073/pnas.1814297116, 2019.

Wang, N., Edtbauer, A., Stönner, C., Pozzer, A., Bourtsoukidis, E., Ernle, L., Dienhart, D., Hottmann, B., Fischer, H., Schuladen, J., Crowley, J. N., Paris, J.-D., Lelieveld, J., and Williams, J.: Measurements of carbonyl compounds around the Arabian Peninsula: overview and model comparison, Atmos. Chem. Phys., 20, 10807-10829, https://doi.org/10.5194/acp-20-108072020, 2020.

Whiticar, M.: Correlation of Natural Gases with Their Sources, in: The Petroleum System - From Source to Trap, edited by: Magoon, L. B. and Dow, W. G., AAPG, Tulsa, USA, 261-283, 1994.

Yacovitch, T. I., Daube, C., and Herndon, S. C., Methane emissions from offshore oil and gas platforms in the Gulf of Mexico, Environ. Sci. Technol., 54, 3530-3538, https://doi.org/10.1021/acs.est.9b07148, 2020.

Yang, E. G., Kort, E. A., Wu, D., Lin, J. C., Oda, T., Ye, X., and Lauvaux, T.: Using space-based observations and Lagrangian modeling to evaluate urban carbon dioxide emissions 
in the Middle East, J. Geophys. Res., 125, e2019JD031922, https://doi.org/10.1029/2019JD031922, 2020.

Yver Kwok, C., Laurent, O., Guemri, A., Philippon, C., Wastine, B., Rella, C. W., Vuillemin, C., Truong, F., Delmotte, M., Kazan, V., Darding, M., Lebègue, B., Kaiser, C., XuerefRémy, I., and Ramonet, M.: Comprehensive laboratory and field testing of cavity ring-down spectroscopy analyzers measuring $\mathrm{H}_{2} \mathrm{O}, \mathrm{CO}_{2}, \mathrm{CH}_{4}$ and CO, Atmos. Meas. Tech., 8, 3867-3892, https://doi.org/10.5194/amt-8-3867-2015, 2015.
Zavala-Araiza, D., Lyon, D. R., Alvarez, R. A., Davis, K. J., Harriss, R., Herndon, S. C., Karion, A., Kort, E. A., Lamb, B. K., Lan, X., Marchese, A. J., Pacala, S. W., Robinson, A. L., Shepson, P. B., Sweeney, C., Talbot, R., TownsendSmall, A., Yacovitch, T. I., Zimmerle, D. J., and Hamburg, S. P.: Reconciling divergent estimates of oil and gas methane emissions, P. Natl. Acad. Sci. USA, 112, 15597-15602, https://doi.org/10.1073/pnas.1522126112, 2015. 